Master submitted for requirement to the degree of Master in Economics

University Beira Interior - Management and Economics Department

"Does trade credit facilitate access to bank finance? An empirical evidence from Portuguese and Spanish small medium size enterprises"

- Andreia Manuela Martins Teixeira -

Advisor: Prof. Doutora Ana Paula Matias Gama

August, 2008 
"Does trade credit facilitate access to bank finance? An empirical evidence from Portuguese and Spanish small medium size" 


\title{
"Does trade credit facilitate access to bank finance? An empirical evidence from Portuguese and Spanish small medium size enterprises"
}

\begin{abstract}
Resumo:
O objectivo deste trabalho de investigação consiste em analisar se o crédito comercial obtido junto dos fornecedores e o endividamento bancário são considerados duas fontes de financiamento substitutas e/ou complementares. Usando uma amostra em dados painel de 468 e 7019 pequenas e médias empresas (PME) Portuguesas e Espanholas respectivamente, e recorrendo ao método de estimação GMM, para controlar potenciais problemas de endogeneidade, os resultados confirmam a hipótese de substituição, isto é, as empresas recorrem ao crédito junto dos fornecedores quando vêm restringido o seu acesso ao financiamento junto dos bancos. Este racionamento no acesso ao crédito bancário é particularmente relevante para as empresas que mantêm uma relação de monopólio (negoceiam com apenas um banco), o que indicia maiores problemas de selecção adversa e risco moral para estas empresas. Todavia, apesar de a hipótese de substituição ser confirmada, a evidência empírica aponta para o facto de que as hipóteses de substituição e complementaridade não serem mutuamente exclusivas, em particular para um grupo específico de empresas: as empresas mais jovens e mais pequenas. Em consonância com as teorias que enfatizam o conteúdo informativo veiculado pelo crédito comercial (qualidade da gestão, nível de risco do cliente), os resultados obtidos confirmam que o recurso ao crédito concedido pelos fornecedores ajuda as empresas mais jovens e mais pequenas a consolidarem a sua reputação no mercado de crédito. $\mathrm{O}$ montante de crédito comercial obtido pode ser visto como um sinal que veicula a informação privada detida pelo fornecedor aos bancos a baixo custo. Neste contexto, os bancos mostram-se mais predispostos a conceder crédito.
\end{abstract}

\begin{abstract}
:
This paper examines if trade credit could be considered as a substitute and/or a complement to bank credit in order to assess the existence of credit rationing. Using a panel dataset of 468 and 7019 Portuguese and Spanish small medium size enterprises, in the period 1998-2006, and controlling for endogeneity problems by using GMM estimators, the results confirm the existence of credit rationing, since the substitution hypothesis is confirmed. This effect is particularly strong for firms that maintaining an exclusive relationship with one bank, which indicate a greater severity of adverse selection problems for those firms. Although the substitution hypothesis is confirmed, the results seem indicate that the substitution and complementary hypothesis are not mutually exclusive, especially for a specific group of firms: the younger and smaller firms. In line with the theories that emphasize the informational role of trade credit, due the informative advantage of suppliers, our empirical results confirm that trade credit allow the younger and smaller firms to improve their reputation, as trade credit reveals the private information of the supplier to the bank, in turn, banks can update their beliefs about customer default risk and agree to increase bank credit.
\end{abstract}

\section{JEL Classifications: G21, G24, G32}

Key words: Small firms finance, credit rationing, trade credit, asymmetric information, bank debt 


\section{Introduction}

The trade credit represents 17.8\% of total assets for all American firms in 1991 and in European countries trade credit represents more than a quarter of total corporate assets (Petersen and Rajan, 1995). These numbers are recently confirmed by Mateut and Mizen (2002). Attending to these numbers a relevant question arises: Why do companies rely on their suppliers to obtain financing, rather than specialized financial intermediaries such as banks?

In fact, in the presence of specialized financial intermediaries, it is far from obvious why the exchange of goods is bundled with a credit transaction: When trade credit is cheaper than bank credit, as is often the case, the puzzle is that suppliers are willing to lend. When trade credit is more expensive, the puzzle is that banks are unwilling to lend. Indeed, a sizeable fraction of firms repeatedly fail to take advantage of early payments discounts and thus end up borrowing from their suppliers at annual interest rates above 40 percent (Petersen and Rajan, 1994, 1997) ${ }^{1}$. Why do not banks increase these firms' credits instead?

A common explanation for trade credit is that suppliers have a monitoring advantage over banks. In the course of business, suppliers obtain information about the borrower which other lenders can only obtain at a cost as argued by Schwartz and Whitcomb, (1978, 1979), Emery, (1987), Freixas, (1993), Biais and Gollier (1997) and Jain, (2001) among others. This is particularly true when the costumers are small, young and opaque firms (Beger and Udell, 1995; Wilner, 2000) or operate in countries with poorly developed financial institutions (Fishman and Love, 2003). Thus equilibrium credit rationing related to ex-ante asymmetric information could result in more use of trade credit (Stiglitz and Weiss, 1981) ${ }^{2}$. Based on these arguments bank and trade credit are two (somehow imperfect) substitutable financial resources, which is referred in the literature as the substitution hypothesis (Meltzer, 1960).

\footnotetext{
${ }^{1}$ See Wilner, (2000) and $\mathrm{Ng}$, et al., (1999) to know how implicit rates can be calculated from trade credit terms.

2 Schwartz (1974) is traditionally considered as the first paper pointing out this aspect.
} 
However, recent theoretical paper such as Biais and Gollier, (1997) and Burkart and Ellingsen, (2004) suggest that bank credit and trade credit could be also be considered two complementary sources of financing.

According to the model of Biais and Gollier (1997) the use of trade credit can alleviate the credit constrains for firms that suffer from imperfect information and credit rationing directly, in accordance with the substitution hypothesis and indirectly. Indirectly because trade credit acts as a signal that reveals supplier's unique information to the bank, than banks which agree to lend when suppliers also lend to their customers.

In their model, credit rationing occurs, in a first round, because the bank can not always assess the quality of a firm with enough precision. As a consequence, some firms with positive net present value projects could not be financed with bank debt. Nevertheless, suppliers could sometimes find it profitable to finance some of these firms and then extend trade credit. In a second round, banks observe this actual use of trade credit and update their beliefs concerning the quality of the firm. When the equilibrium is reached, some firms which would have suffered from credit rationing in the absence of trade credit finance actually finance net present value projects with a mix of trade credit and bank credit. Based on the result of this equilibrium game model, trade credit and bank credit are two complementary resources which are referred to as the complementary hypothesis ${ }^{3}$. The agency mode of Bukart and Ellingsen (2004) reaches a similar result. In their model, additional trade credit increases the investment size and thereby the entrepreneur's residual return and hence decreases the entrepreneur's incentive to divert cash. As a consequence bank debt limit increases, making bank debt and trade credit complements.

The main objective of this paper is to provide empirical evidence if trade credit could be considered as a substitute and/or as a complement to bank debt in order to assess the existence of credit rationing. More specifically, we analyse if trade credit could contribute to build a "good reputation" in the borrower market, in other words, the

\footnotetext{
${ }^{3}$ See Bond (2005), Berlin (2003) and Burkart, et al., (2004) for recent assessments on the nature of trade credit vis-à-vis bank debt.
} 
availability of trade credit facilitates the access to bank credit, especially for young small firms, due to their financial opacity.

A panel dataset of small medium size (SME) of Portuguese and Spanish firms in the period 1998-2006 is used to test the complementary role of trade credit versus the substitution hypothesis. The option to study Portuguese and Spanish firms is sustained in the evidence provided by Breig (1994). According to Breig (1994) trade credit tends to be more used in countries bank based oriented comparing to economies where financial markets play an information transmission and monitoring role such as the United States. In fact, the previous research has been conducted in the United States, a country strongly immersed in the common-law system ${ }^{4}$. We define the common-law model, which is built on Anglo-Saxon principles, as one with the pronounced leaning towards market, as opposed to bank debt financing. Legally, a common-law model is characterized by its relative strong protection to minority investors. Conversely, the European continental civil-law model is characterized by bias towards bank debt financing and relative minority-investor protection $^{5}$. In this research, we broaden the previous research by looking at Portugal and Spain, civil-law countries, which have a financial system dominated by the presence of financial intermediaries, mostly banks.

The focus on small firms can be explained for various reasons. First, small firms are more likely to suffer information problems in capital markets. They are typically restricted to obtaining external finance only from financial institutions and suppliers. Public markets are only accessible for large firms. Second, due to the lack of credit history, the impossibility to credibly disclose their quality and the lack of separation between ownership and management the asymmetric information increases between insiders and outsiders (lenders). Third, SME play an important role in the world economies (Berger and Frame, 2006). In Portugal, SME are responsible for 75 percent and 83 percent of employment in industry and services respectively. A

\footnotetext{
${ }^{4}$ Only a few papers address the complementary role of trade credit versus the substitution hypothesis. Petersen and Rajan (1997) addresses this important role of trade credit for the United States. An exception was Cook (1997), who studies this topic for Russia data.

${ }^{5}$ Fishman and Love (2003) and Demirgüç-kunt and Maksiovic (2001) pointed out that trade credit is more prevalent in countries with less efficient legal systems.
} 
similar situation is found in Spain (the percentage of employment created in industry and services is 72 percent and 79 percent, respectively) (IAPMEI, 2007).

The study is structured in the following way. In the next section, a brief review of the literature is compiled. In the third section, data is presented and the methodology used for contrasting our hypothesis is described. In the forth section, the relation between trade credit and bank debt and the effect of the strength of banking relationship on the availability of bank credit are studied. In the final section, the main conclusions are stated.

\section{Literature Review}

There are a number of empirical findings suggesting that firms suffering from credit rationing use trade credit. Nilsen (2002) finds that during monetary contractions, small firms are likely to be particularly bank credit rationed, react by borrowing more from their suppliers. Similar empirical evidence is provided by Biais et al., (1995) and Petersen and Rajan (1994, 1995). According to these authors small firms which are more likely to be credit rationed, tend to rely more on trade credit ${ }^{6}$.

These empirical findings raise a question: Why is trade credit available when bank credit is rationed? Suppliers are themselves more likely to be credit constrained and to have high cost of funds than banks. Hence when banks cannot lend, suppliers should not be able to lend either.

There are a broader set of trade credit theories. A notable contribution is the work of Nadiri (1969). Nadiri was the first author to formally consider trade credit extension as part of an optimal selling policy. With the advent of contract theory authors have identified more precisely how the extension of trade credit differs from a decrease in price or an increase in advertising, and why trade credit is not crowed. Another early theoretical contribution is Ferris (1981), who argues that trade credit, allows the suppliers and the customers to pool liquidity risks. However, Ferris (1981) does not explain why the risk pooling not handled by financial intermediaries. Other

\footnotetext{
${ }^{6}$ Trade credit tends to be more important for unlisted firms (Giannetti, 2003), except possibly in the United States (Petersen and Rajan, 1997).
} 
explanations of used of trade credit are based on buyers' private information about their own willingness or ability to pay and the seller's resulting incentive to price discriminate (Smith, 1987; Brennan et al., 1988); on suppliers private information about product quality (Smith, 1987; Lee and Stowe, 1993; Long et al., 1993); trade credit serves as a warranty for product quality (Long et al.,1993); on suppliers' advantage in liquidating collateral (Frank and Maksimovic, 2005); on taxes effect (Brick and Fung, 1984) and on long-term buyer/seller relationships (Wilner, 2000). For a historical account of trade credit see Cameron (1967).

More recently, assuming the assumption that suppliers have private information about their customers, in the course of business, suppliers obtain information about borrower which other lenders can only obtain at a cost. Biais and Gollier (1997) demonstrate theoretically that trade credit can facilitate aggregation of the supllier's information with the bank's information and thus alleviate an information asymmetry which otherwise would preclude financing of positive net present value (NPV) projects. Consider a market for an input good. There are different types of buyers. Some are "good", the projects for which they need the input have positive NPV. Other buyers (the "bad") have negative NPV projects. The buyers privately know their own type, while the bank and the supplier only have different signals about it. When bank credit is the only source of financing, if the proportion of negative NPV buyers is large and if the information of the banks is not precise, all buyers, including the "good", are denied credit. These prevent them from buying the input and investing in positive NPV projects. For these authors this credit market breakdown is due to asymmetric information as credit rationing ${ }^{7}$.

In contrast, when trade credit can be used and if sellers have sufficient expected future cash-flows to pledge collateral ${ }^{8}$, there exists a separating equilibrium where sellers extend trade credit to their customers only if they have received a good signal, and where the positive information contained in the availability of trade credit

\footnotetext{
7 This definition is in spirit of the definition of Stiglitz and Weiss (1981) that relates the market breakdown to asymmetric information.

8 According to Burkart and Ellingsen (2004), firms simultaneously give and take credit because receivables can be collateralized. Once an invoice is pledge as collateral, it becomes completely illiquid from the firms perspective, and the firm can obtain additional bank credit against the receivables. Thus, offering an additional dollar of trade credit does not force a firm to reduce its real investment by one dollar.
} 
induces the bank to also lend (if they also have received a good signal). In this context, trade credit plays an important role because it is a credible way for the seller to convey its private information to the bank. If the seller is willing to extend trade credit, and thus to bear the default risk of the buyer, it must be that it has good information about the latter. On observing this, the bank updates positively its beliefs about the buyer, and therefore agrees to lend. In other words, trade credit enables the private information of the seller to be used in the lending relationship, and this additional information can alleviate credit rationing due to adverse selection.

For Burkart and Ellingsen (2004) the monitoring advantage theory is intuitively appealing; however the existing models suffer from tow shortcomings. First, they fail to explain why a bank, being specialized in the evaluation of borrowers' creditworthiness, would have less information than suppliers do. Second, if it is accepted that suppliers have information that banks do not have, why the theories do not explain why suppliers regularly lend inputs, but only very rarely lend cash.

Starting with the conventional idea that moral hazard at the investment stage gives rise to credit rationing of poor entrepreneurs, the main innovation of the Burkart and Ellingsen (2004) model is that the source of the suppliers' informational advantage is the input transaction itself, that is, unlike other lenders an input supplier automatically knows that an input transaction has been completed. Other lenders can only obtain this information by incurring monitoring costs. The value of input monitoring stems in turn from the fundamental difference between inputs and cash. Cash is easily diverted in particular if diversion is interpreted broadly as any use of resources which does not maximize the lenders' expected return. Most inputs are less easily diverted, and input illiquidity facilitates trade credit ${ }^{9}$.

A salient result of input transaction model is that the availability of trade credit increases in the amount that banks are willing to lend. For a given bank loan additional trade credit permits the borrower higher levels of diversion as well as investment. However, due to the relative illiquidity of trade credit the borrower's

\footnotetext{
9 The idea that illiquid assets facilitate borrowing by limiting the borrower's discretion has earlier been explored by Myers and Rajan (1998). They argue that banks are able to attract depositors precisely because banks' loan portfolios are relative illiquid.
} 
return from investing increases by more than the return from diversion. Anticipating the availability trade credit boots investment rather than diversion, banks are willing to increase their lending ${ }^{10}$.

In summarize, according to these two recent theoretical papers (Bias and Gollier, 1997; Burkart and Ellingsen, 2004), there is one possible answer to the question: "Why trade is trade credit available when bank credit is rationed?", trade credit enables the private information of the seller to be used in the lending relationship. In other word, lending through trade credit has an informational role.

\section{Data and Methodology}

The data of this research were obtained from AMADEUS, a dataset collected by Bureau Van Dijk. This database includes standardised annual accounts (consolidated and unconsolidated) for approximately 9 millions of companies through Europe, including Eastern Europe. Due to the fact, that we have only have access to the Amadeus dataset since 1998, this imposition 1998 the year as a starting point for our analysis. To be included in the dataset, the firms must have at least one employee and had fulfilled the requirements established in the European Commission Recommendation of 6 May $2003(2003 / 361 / E C)^{11}$. If not consolidated and non consolidated accounts are available, we choose the non consolidated ones. In order to control the survivor bias effect, we selected active and inactive firms operating in Manufacturing of Food Products and Beverages (Sub-section DA, NACE codes 15 and 16). The option to study this sector is justified based on the fact that the percentage of small firms operating in Portugal and Spain is similar (about 7 percent), when compared with the total number of Portuguese to Spanish SME. This is a guarantee of the representation of our samples in the two countries. Because our main focus of analysis is small young firms, firms with more than 25 years were dropped. After eliminating firms with too many missing and inconsistent data (e.g.

10 The main distinction between the agency model of Biais and Gollier (1997) and the input transaction model of Burkart and Ellingsen (2004) is: whereas the first model focuses on the borrower screening, the second model is concerned with borrower moral hazard. In fact, in screening models there is no distinction between cash and lending inputs.

${ }^{11}$ According to the European Commission Recommendation (2003/61/CE) to be considered a small firm, for at least two criteria need to be respected: i) having less than 250 employees and ii) having an annual business volume not exceeding $€ 50$ million or assets not exceeding $€ 43$ million. 
total assets are different from total shareholders funds plus liabilities), our final sample consists of an unbalanced panel data of 468 and 7019 Portuguese and Spanish SME, respectively for the period of 1998 - 2006.

To contrast if the trade credit is a substitute and/or a complement of bank debt in order to assess the existence of credit rationing, we express a model as follows:

$$
\mathrm{Y}_{i t}=\alpha+\sum_{j=1}^{J} \beta_{j} X_{i j}+\eta_{i}+\lambda_{t}+v_{i t}
$$

where $\mathrm{X}$ stands for the $\mathrm{j}$ factors considered for each firm $\mathrm{i}, \eta_{\mathrm{i}}$ is the firm fixed effects, $\lambda_{\mathrm{t}}$ is year fixed-effects and $v_{\mathrm{it}}$ is the error term.

The dependent variable, following Blasio (2005) is the ratio of the difference between debtors and creditors to total assets - trade credit (TC). To examine how the company i resorts the credit from suppliers when facing different values of banking financing in studied periods, we use the variable bank credit (BC) which has been proxied with the ratio of bank debt to total assets as an independent variable. We also include the variables age and size as in dependent variables. According to Berger and Udell $(1995,1998)$ the age of the firm reflects the reputation that is openly transmitted to the market; it plays a different role from the information that bank acquires through the level of trade credit used by the firm. The variable age is defined as the natural logarithm of the time elapsed between firms founding date and the year of measurement. Another source of public information about the firm comes from its balance sheet. The financial statements can provide information by which we can assess the risk of the company, such as its size, capacity for generating internal funds and financial leverage. Berger and Udell $(1998,2002)$ consider that the size of the borrower to be an inverse measure of its information opaqueness, as smaller companies use likely to be in poorer financial condition and have less experience and less public information available to the public. We use the natural logarithm of total assets to proxy for the size of the firm. ${ }^{12}$ In attempt to explain variations in the use of trade credit by firms, we also include as independent

\footnotetext{
12 Firm size may be related to many other concerns than financial opacity, Beck et al. (2003) provide
} several interpretations of the determinants of firm size. 
variables asset structure, accounts turnover, inventory turnover, sales growth, liquidity and profitability (see Appendix I for a detailed definition of variables) ${ }^{13}$.

We first analyse the relationship between trade credit and bank debt in order to assess the existence of credit rationing. The evaluation of this link could indicate the presence of adverse selection that prevents firms from obtaining the bank financing they need. Next, we complete our study analysing if information conveyed by trade credit could affect the level of indebtedness of small firms. In order to do so we investigate the nexus between the level of debt and the interest rate. In this way we test how financial institutions price the debt they lend to small firms depending on the strength of their relationship. To do this, we split the sample into companies which obtain funds from just one bank than those doing so from several banks, by introducing a dummy variable that takes the value 1 if the firm obtains funds from just one financial institution, and zero otherwise.

In order to test this point, the dependent variable is bank credit. The independent variables include: i) interest has been proxied with the ratio of financial expenses to bank debt; ii) debt coverage; iii) tangibility which is also a proxy for the ability to pledge collateral; iv) the Altman Z-Score to capture the firms credit risk; v) age; vi) size and vii) trade credit (see Appendix I for a detailed definition of variables).

The model (1) assumes that bank debt is exogenous or pre-determinate. However, we argue that trade credit is used in spite of the high interest rates implicit delayed payment prices (Wilner, 2000). It might seem paradoxical that firms would be using simultaneously two sources of financing, one being more expensive than other. But if they did not use trade credit than information from the seller could not be conveyed to the bank and the availability of credit and relative low bank rate would not be granted. This is especially true for small young firms due to their financial opacity (Biais and Gollier, 1997; Burkart and Ellingsen, 2004). Thus bank debt is potentially endogenous with trade credit, which would lead to inconsistent estimations for the model proposed above.

\footnotetext{
${ }^{13}$ All the variables have been taken from studies into the determining factors of trade credit (Petersen and Rajan, 1997; Blasio, 2005).
} 
We address this potential problem of reverse causality by using the Generalized Method of Moments (GMM) (Arellano, 2003), which allows us to control for endogeneity by using instruments. Specially, we follow the estimation strategy proposed by Arellano and Bond (1991), which consists of using all the right-hand side variables lagged twice or more as instruments. ${ }^{14}$

This methodology assumes that there is no second-order serial correlation in the errors in first differences. For this reason, in order to test the consistency of the estimations, we used the test for the absence of second-order serial correlation proposed by Arellano and Bond (1991). Similarly, we employ the Sargan test for the over-identifying restrictions, which tests for the absence of correlation between instruments and the error term.

A second estimation problem comes from the fact that it is possible that the relation between trade credit and bank debt is neither a correlation running from bank debt to trade credit nor a reverse correlation, but rather a spurious relationship attributed to unobservable individual heterogeneity among firms. For instance, a manager with good negotiation skills may be able to maintain strong relationships with suppliers and at the same time be able to bargain debt to a lower cost. Using panel data is a way to solve the endogeneity caused by spurious relationship. The parameters $\lambda_{t}$ are temporary dummy variables that change over time, but are equal for all firms in each period considered. In this way, we have tried to include the economic variables which firms cannot control (interest rates, prices for example) ${ }^{15}$.

Table I presents the mean value of different magnitudes by age of the firm's age (Panel A) and its size (Panel B).

\footnotetext{
${ }^{14}$ It could also be argued that both, bank credit and interest rate are also endogenous variables. Using the GMM in the estimation of the model helps to control for this hypothetic problem.

15 It should be emphasized that the use of trade credit is also related to macroeconomic factors (Meltzer, 1960; Bernanke and Blinder, 1988; Ramey, 1992; Nilsen, 2002 and Blasio, 2005).
} 
TABLE I

Distribution of Sample by Age and Size

\begin{tabular}{|c|c|c|c|c|c|c|c|c|c|c|}
\hline & \multicolumn{5}{|c|}{ Spain } & \multicolumn{5}{|c|}{ Portugal } \\
\hline & $\begin{array}{l}(\%) \text { of } \\
\text { firms }\end{array}$ & $\begin{array}{c}\operatorname{DBank}^{\mathrm{a}} \\
(\%)\end{array}$ & $\begin{array}{c}\mathrm{DBank}^{\mathrm{b}} \\
(\%)\end{array}$ & $\begin{array}{l}\text { Bank } \\
\text { Credit }^{\mathrm{c}} \\
(\%)\end{array}$ & $\begin{array}{c}\text { Trade } \\
\text { Credit }^{\mathrm{d}} \\
(\%)\end{array}$ & $\begin{array}{l}(\%) \text { of } \\
\text { firms }\end{array}$ & $\begin{array}{c}\mathrm{DBank}^{\mathrm{a}} \\
(\%)\end{array}$ & $\begin{array}{c}\mathrm{DBank}^{\mathrm{b}} \\
(\%)\end{array}$ & $\begin{array}{c}\text { Bank } \\
\text { Credit }^{\mathrm{c}} \\
(\%)\end{array}$ & $\begin{array}{c}\text { Trade } \\
\text { Credit }^{\mathrm{d}} \\
(\%)\end{array}$ \\
\hline \multicolumn{11}{|c|}{ Panel A: Distribution of Sample by age } \\
\hline $\begin{array}{c}\text { Infant } \\
{[0,5]}\end{array}$ & 3.38 & 55.07 & 29.26 & 28.44 & 20.82 & 3.70 & 46.15 & 30.77 & 27.17 & 23,06 \\
\hline $\begin{array}{c}\text { Adolescent } \\
\text { ]5,10] }\end{array}$ & 8.11 & 56.09 & 28.85 & 25.14 & 20.41 & 6.75 & 52.00 & 32.00 & 30.22 & 22,59 \\
\hline $\begin{array}{l}\text { Middle- } \\
\text { age } \\
\text { ]10;15] }\end{array}$ & 12.88 & 51.70 & 30.96 & 21.64 & 19.42 & 12.95 & 22.73 & 40.90 & 23.09 & 17,88 \\
\hline $\begin{array}{c}\text { Old firms } \\
] 15 ; 25]\end{array}$ & 19.64 & 48.78 & 26.83 & 17.68 & 22.28 & 19.62 & 26.00 & 26.00 & 25.37 & 18,29 \\
\hline \multicolumn{11}{|c|}{ Panel B: Distribution of Sample by size ${ }^{\mathrm{e}}$} \\
\hline $\begin{array}{l}\text { Micro } \\
\text { firms }\end{array}$ & 0.12 & 55.62 & 29.30 & 19.14 & 35.88 & 0,67 & 64.06 & 25.000 & 20.02 & 26,18 \\
\hline $\begin{array}{l}\text { Small } \\
\text { firms }\end{array}$ & 26,69 & 50.89 & 28.63 & 22.92 & 18.38 & 50,17 & 35.78 & 35.29 & 30.74 & 19,07 \\
\hline $\begin{array}{l}\text { Medium } \\
\text { firms }\end{array}$ & 73,19 & 20.00 & 20.00 & 39.36 & 21.60 & 49,15 & 12.94 & 22.75 & 60.90 & 12,09 \\
\hline
\end{tabular}

${ }^{a}$ Bank1 is a dummy variable which takes the values one if the firm obtain funds from just one financial institution, and zero otherwise.

${ }^{\mathrm{b}}$ DBank2 is a dummy variable which takes the values one if the firm obtain funds from two financial institutions, and zero otherwise.

${ }^{\mathrm{c}}$ Bank credit is the ratio of bank debt to total assets.

d Trade credit is the ratio of (debtors - creditors) to total assets.

${ }^{\mathrm{e}}$ Size is the natural logarithm of total assets.

When analysed by age Spanish SME report the same amount of bank credit and trade credit. For Portuguese SME, the younger firms exhibit more bank credit and also trade credit $^{16}$.

In contrast, the medium and older firms show a higher financial leverage. This could be due to the result of the consolidation of the company's reputation. The dummy variables in both samples indicate that older and large firms work with more lenders. It would seem logical that the complexities deriving from size may encourage large firms to divide their business across several banks. In addition lenders likely want to maintain their connections with larger firms because they can be overseen more

\footnotetext{
${ }^{16}$ We classify firms according to the age in line with Berger and Udell (2002).
} 
easily. The descriptive statistic and the correlations for both of samples are presented in appendix II, III, IV and V.

\section{Analysis of the results}

\subsection{Relation between trade credit and bank credit}

In the presence of asymmetry information Myers and Majluf (1984) claim that companies establish a hierarchy of sources to be used for financing, preferring those carrying a lower cost, and also a lower risk. If it is assumed that suppliers offer discounts for prompt payment, then resorting to the delayed payment facility thereby offered becomes a form of financing that is more expensive than bank loans (Wilner, 2000). It might seem paradoxical that firms would use simultaneously two sources of financing, one being more expensive than the other. However, our main argument, and in line with the models of Biais and Gollier (1997) and Burkart and Elligsen (2004), is if the small young firm did not use trade credit, then information from seller could not be conveyed to the banks, consequently banks are not willing to lend ${ }^{17}$. In order to contrast the relation between trade credit and bank credit, and tacking into account model (1), we specify trade credit model as the following:

$$
\mathrm{TC}_{\mathrm{it}}=\alpha_{0}+\beta_{1} B C_{i t}+\sum_{j=1}^{J} \beta_{j} X_{i j}+\eta_{i}+\lambda_{t}+v_{i t}
$$

\footnotetext{
${ }^{17}$ It should be pointed out that the existence of trade credit on firm's balance sheet does not mean that it has exhausted its capacity to borrow from bank. It is well-known that suppliers grant some of their credit without charge and firms therefore use these funds before resorting to bank debt. Nevertheless, these free resources are not unlimited.
} 
TABLE II

The relationship between trade credit and bank credit

\begin{tabular}{|c|c|c|c|c|c|c|c|c|}
\hline & \multicolumn{4}{|c|}{ Spain } & \multicolumn{4}{|c|}{ Portugal } \\
\hline & $\begin{array}{c}\text { Regression } \\
\text { Trade Credit (1) }\end{array}$ & $\begin{array}{c}\text { Regression } \\
\text { Trade Credit (2) }\end{array}$ & $\begin{array}{c}\text { Regression } \\
\text { Trade Credit (3) }\end{array}$ & $\begin{array}{c}\text { Regression } \\
\text { Trade Credit (4) }\end{array}$ & $\begin{array}{c}\text { Regression } \\
\text { Trade Credit (1) }\end{array}$ & $\begin{array}{c}\text { Regression } \\
\text { Trade Credit (2) }\end{array}$ & $\begin{array}{c}\text { Regression } \\
\text { Trade Credit (3) }\end{array}$ & $\begin{array}{c}\text { Regression } \\
\text { Trade Credit (4) }\end{array}$ \\
\hline Bank Credit $_{1}$ & $\begin{array}{l}-0.011^{* *} \\
(-2.529)\end{array}$ & --------- & $\begin{array}{l}-0.013^{* * * * *} \\
(-29.404)\end{array}$ & $\begin{array}{l}-0.008^{*} \\
(-1.714)\end{array}$ & $\begin{array}{l}-0.006 \\
(-3.727)\end{array}$ & --------- & 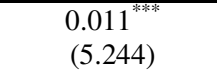 & $\begin{array}{l}0.011^{* * * *} \\
(6.109)\end{array}$ \\
\hline Bank Credit $_{2}$ & ---------- & $\begin{array}{l}-0.311^{* * * *} \\
(-12.855)\end{array}$ & ----------- & ---------- & ---------- & $\begin{array}{l}-0.080^{* * * *} \\
(-41.441)\end{array}$ & ---------- & ----------- \\
\hline $\begin{array}{c}\text { DBank } 1 * \text { Bank } \\
\text { Credit }_{1}\end{array}$ & ---------- & ---------- & ---------- & $\begin{array}{l}-0.021^{*} \\
(-1.900)\end{array}$ & ---------- & ---------- & ---------- & $\begin{array}{l}-0.073^{* * *} \\
(-27.000)\end{array}$ \\
\hline Size & $\begin{array}{c}0.016^{* * *} \\
(3.874)\end{array}$ & $\begin{array}{c}0.017^{* * * *} \\
(4.469)\end{array}$ & $\begin{array}{l}0.007^{* * *} \\
(69.767)\end{array}$ & $\begin{array}{l}0.016^{* * * *} \\
(3.912)\end{array}$ & $\begin{array}{l}0.017^{* * *} \\
(29.687)\end{array}$ & $\begin{array}{l}0.023^{* * *} \\
(39.727)\end{array}$ & $\begin{array}{l}0.019^{* * *} \\
(29.517)\end{array}$ & $\begin{array}{l}0.017^{* * *} \\
(29.630)\end{array}$ \\
\hline Age & $\begin{array}{c}-0.023^{* * * *} \\
(-5.003)\end{array}$ & $\begin{array}{l}-0.022^{* * *} \\
(-5.202)\end{array}$ & ----------- & $\begin{array}{c}-0.023^{* * *} \\
(-5.070)\end{array}$ & $\begin{array}{l}-0.037^{* * * *} \\
(-22.052)\end{array}$ & $\begin{array}{l}-0.059^{* * * *} \\
(-30.420)\end{array}$ & --------- & $\begin{array}{l}-0.037^{* * *} \\
(-21.778)\end{array}$ \\
\hline Asset Structure & $\begin{array}{l}0.517^{\text {**** }} \\
(72.346)\end{array}$ & $\begin{array}{l}0.521^{\text {**** }} \\
(73.676)\end{array}$ & $\begin{array}{c}0.472^{* * *} \\
(1126.923)\end{array}$ & $\begin{array}{l}0.517^{* * * *} \\
(72.327)\end{array}$ & $\begin{array}{l}0.254^{* * *} \\
(69.550)\end{array}$ & $\begin{array}{l}0.280^{* * * *} \\
(60.431)\end{array}$ & $\begin{array}{l}0.288^{* * * *} \\
(75.768)\end{array}$ & $\begin{array}{l}0.251^{* * * *} \\
(68.638)\end{array}$ \\
\hline $\begin{array}{l}\text { Accounts } \\
\text { Turnover }\end{array}$ & $\begin{array}{l}0.000^{* * *} \\
(2.047)\end{array}$ & $\begin{array}{l}0.000^{* * *} \\
(2.214)\end{array}$ & $\begin{array}{l}0.000^{* * *} \\
(16.195)\end{array}$ & $\begin{array}{l}0.000^{* *} \\
(2.087)\end{array}$ & $\begin{array}{c}0.001^{* * *} \\
(3.248)\end{array}$ & $\begin{array}{l}0.010^{* * * *} \\
(42.072)\end{array}$ & $\begin{array}{c}-0.000 \\
(-1.047)\end{array}$ & $\begin{array}{c}0.000 \\
(0.227)\end{array}$ \\
\hline Liquidity & $\begin{array}{l}0.000^{*} \\
(1.907)\end{array}$ & $\begin{array}{c}0,000^{*} \\
(1.863)\end{array}$ & $\begin{array}{l}0.000^{* * * *} \\
(9.318)\end{array}$ & $\begin{array}{l}0.000^{*} \\
(1.897)\end{array}$ & $\begin{array}{l}0.049^{* * * *} \\
(79.927)\end{array}$ & $\begin{array}{c}0.074^{* * * *} \\
(115.182)\end{array}$ & $\begin{array}{l}0.036^{* * * *} \\
(65.627)\end{array}$ & $\begin{array}{l}0.049^{* * *} \\
(79.546)\end{array}$ \\
\hline Profitability & $\begin{array}{l}0.011^{*} \\
(1.757)\end{array}$ & $\begin{array}{l}0.012^{*} \\
(1.904)\end{array}$ & $\begin{array}{l}-0.024^{* * * *} \\
(-44.185)\end{array}$ & $\begin{array}{l}0.011^{*} \\
(1.808)\end{array}$ & $\begin{array}{l}-0.000 \\
(-1.529)\end{array}$ & $\begin{array}{c}0.000 \\
(0.081)\end{array}$ & $\begin{array}{l}-0.002^{* * * *} \\
(-8.553)\end{array}$ & $\begin{array}{l}-0.000^{*} \\
(-1.690)\end{array}$ \\
\hline $\begin{array}{l}\text { Inventory } \\
\text { Turnover }\end{array}$ & $\begin{array}{c}0.000^{* * * *} \\
(2.628)\end{array}$ & $\begin{array}{c}0.000^{* * * *} \\
(2.665)\end{array}$ & $\begin{array}{l}0.000^{* * *} \\
(80.126)\end{array}$ & $\begin{array}{l}0.000^{* * * *} \\
(2.622)\end{array}$ & $\begin{array}{c}0.000^{* * * *} \\
(7.109)\end{array}$ & $\begin{array}{c}0.000^{* * * *} \\
(4.436)\end{array}$ & $\begin{array}{c}0.000^{* * * *} \\
(7.977)\end{array}$ & $\begin{array}{l}0.000^{* * * *} \\
(7.452)\end{array}$ \\
\hline Sales Growth & $\begin{array}{c}-0.000 \\
(-0.576)\end{array}$ & $\begin{array}{c}-0.000 \\
(-0.610)\end{array}$ & $\begin{array}{l}-0.000^{* * * *} \\
(-14.989) \\
0.006^{* * *}\end{array}$ & $\begin{array}{l}-0.000 \\
(-0.580)\end{array}$ & $\begin{array}{l}0.000^{* * * *} \\
(7.695)\end{array}$ & $\begin{array}{c}0.000 \\
(3.445)\end{array}$ & $\begin{array}{l}0.000^{* * *} \\
(11.512) \\
0.052^{* * *}\end{array}$ & $\begin{array}{l}0.000^{* * * *} \\
(7.915)\end{array}$ \\
\hline $\begin{array}{l}\text { Dage }_{1} \\
\text { Dage }_{2}\end{array}$ & ---------- & ---------- & $\begin{array}{l}(12.806) \\
0.005^{* * *} \\
(14.233) \\
-0.001^{* * *}\end{array}$ & ----------- & -------- & --- & $\begin{array}{l}(16.782) \\
0.066^{* * * *} \\
(21.882) \\
0.056^{* * * *}\end{array}$ & ------- \\
\hline $\mathrm{Dage}_{3}$ & -------- & ------- & $(-2.773)$ & ------- & & 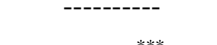 & (14.187) & 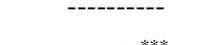 \\
\hline Constant & $\begin{array}{l}-0.06^{* *} \\
(-2.421)\end{array}$ & $\begin{array}{l}-0.066^{* * * *} \\
(-2.991)\end{array}$ & $\begin{array}{l}-0.034^{* * * *} \\
(-51.633)\end{array}$ & $\begin{array}{l}-0.058^{* *} \\
(-2.416)\end{array}$ & $\begin{array}{l}-0.056^{* * * *} \\
(-14.008)\end{array}$ & $\begin{array}{l}-0.079^{* * * *} \\
(-15.927)\end{array}$ & $\begin{array}{l}-0.218^{* * * *} \\
(-39.480)\end{array}$ & $\begin{array}{l}-0.053^{* * * *} \\
(-12.889)\end{array}$ \\
\hline Sargan Test & 0.985 & 0.968 & 0.943 & 0.957 & 0.754 & 0.619 & 0.701 & 0.820 \\
\hline Hausman Test $\left(\chi^{2}\right)$ & 142.320 & 133.077 & 117.496 & 163.900 & 38.864 & 36.753 & 15.848 & 50.920 \\
\hline $\begin{array}{l}\text { 1- All regressions ar } \\
\text { 2- According to the } \\
\text { 3- Trade credit whic } \\
\text { regressions (1), } \\
\text { dummies variable } \\
\text { **** Significant at } 1 \% \text {. }\end{array}$ & $\begin{array}{l}\text { Imated by using } \\
\text { man Test, the tri } \\
\text { proxied with the } \\
d \text { (4) in both of } \\
\text { t take value one } \\
\text { gnificant at } 5 \% \text {. }\end{array}$ & $\begin{array}{l}\text { 4, which are robi } \\
\text { edit model for th } \\
\text { of the differenc } \\
\text { les. In model } 2 \\
\text { age of the firm i }\end{array}$ & $\begin{array}{l}\text { o the heteroceda } \\
\text { pain sample is es } \\
\text { tween debtors a } \\
\text { h samples) the } \\
\text { tween } 0 \text { and } 5 \text { y }\end{array}$ & $\begin{array}{l}\text { Sargan Test, t } \\
\text { d by fixed - ef } \\
\text { ditors to total a } \\
\text { e bank credit i } \\
\text { to } 10 \text { years an }\end{array}$ & or Portuguese & $\begin{array}{l}\text { ification. T-Stat } \\
\text { the estimation } \\
\text { ole. Bank credit }\end{array}$ & $\begin{array}{l}\text { are in parenthese } \\
\text { ed on random eff } \\
\text { e ratio of bank d } \\
\text { The variable Dag } \\
\text { f other variables }\end{array}$ & $\begin{array}{l}\text { total assets for t } \\
\text { age }_{2} \text { and Dage }{ }_{3} \text { a } \\
\text { ppendix I. }\end{array}$ \\
\hline
\end{tabular}


In order to contrast the correlation between the individual effects $\left(\eta_{\mathrm{i}}\right)$ and the independent variables, the Hausman test was used (Hausman, 1978). According to this test, if the effects are uncorrelated with the independent variables, the fixed-effects and random-effects estimates should not be significantly different. Following this procedure, the Hausman test shows that for the Spanish sample the independent variables are correlated with non-observable heterogeneity. For this sample we use the fixed effects models. We include firm and year fixed-effects. For Portuguese sample the fixed-effects and random-effects estimators are not statically different. The random-effects estimators are used. $^{18}$

Observing the results reported in Table II, model 1, the coefficient of the variable bank credit, is negative and statically significant for both samples. This result is consistent with the substitution hypothesis which states that firms use trade credit, in spite of its high cost.

With effect, it has been found that the coefficient of the variable age is negative and statistically significant at one percent level, which means that old firms may have lower financial needs and may prefer internal financing (resulting from retained earnings).This result is strengthened by the variable size. The large firms are less opaque, it is reasonable to assume that suppliers offer more credit to firms of higher quality. Suppliers may want to protect the value of its implicit equity stake of the customer - the present value of the margins they makes on current and future sales, specially in growing firms (Petersen and Rajan, 1997).

As for other control variables, they are positive and statically significant, which indicate in line with the results reported by Emery (1987) and Fishman and Love (2003) that trade credit may be related to firm's revenues and current assets items such as accounts and inventory turnover, liquidity, profitability, which are themselves related to a firm's field of activity or industry. For example firm's with more liquidity, higher values for accounts turnover, inventory turnover which proxy for the quality of management increase their level of trade credit.

\footnotetext{
${ }^{18}$ We used only random effects for firms. With unbalanced panel data the estimation using firm and period random effects are not allowed in the econometric software Eviews version 6.0.
} 
Detragiache et al. (2000), claim that asymmetric information presents small firms from renewing their loans. It is understandable to observe a more direct substitution between trade credit and short term loans. Following Berger and Udell (1995) we focus on model 2 exclusively in short term debt $\left(\mathrm{BC}_{2}\right)$. As we expected, for both of samples, the coefficient of bank credit $2\left(\mathrm{BC}_{2}\right)$ is negatively and statically significant at one percent level. The results are consistents with model (1) for remaining variables.

These results are consistent with empirical evidence (Wilner 2000; Blasio, 2005; Petersen and Rajan 1997), indicating that trade credit is an expense substitute for bank debt, confirming that the small firms of this sample are credit rationed.

Next, one could wonder why suppliers should extend, credit to companies that have been rationed by the banks. According to Biais and Gollier (1997) and Burkart and Ellingsen (2004), the suppliers have a comparative advantage over traditional financial intermediaries in collecting information on other non-financial firm's, in assessing their credit worthiness and finally in controlling their actions.

Based on this informativeness advantage, we introduce in the model (3) for both samples, dummies variables for age. ${ }^{19}$ As pointed out by Berger and Udell $(1995,1998)$ age reflects public information, whereas the strength of the relationship, with banks and/or suppliers, reflects private information, available only to the lender and corresponds to the difference between information obtained as a result of reputation versus information obtained from monitoring.

As we expected the variable age is positively and statistically significant at one percent level related with trade credit for young and small firms (infant and adolescent firms). For older firms we obtain an opposite coefficient, which reinforce the result that the small firms of this sample are credit rationed.

The positive relationship between young firms and trade credit could be explained because trade credit helps to solve principal agent problems of managerial behaviour, more pronounced for small firms due to the lack of separation between ownership and

\footnotetext{
${ }^{19}$ We also include the square of the variable age to account for the possibility of non-linearity. The variable appears non significant and was eliminated from the models.
} 
management, in line with the complementary hypothesis. In fact, suppliers have abilities to circumcise the traditional problems of informational asymmetry and moral hazard at least as well, if not better than banks: i) suppliers are supposed to possess a better knowledge of the technology and of the markets of its customers and hence can appraise their quality with a great precision than banks do; ii) suppliers may also threaten to stop future supplies and may be in a better position to repossess and resell goods in case of default than banks and iii) in lending goods, not cash as banks do, suppliers are less concerned with cash diversion by their customers (Petersen and Rajan, 1997:689).

If it is accepted that the cost of trade credit is higher than bank debt and small firm's tend to experience a more rapid growth than old firms is quite understandable that a company will increase the former when bank debt is run out and it still has unsatisfied demand for funds. ${ }^{20}$ Furthermore, since the possibility of resorting to alternative financing sources apart from trade credit depends on the problems raised by adverse selection, the degree of substitution between trade credit and bank credit is expected to be higher for firms that are subject to a greater monopoly ${ }^{21}$.

In order to distinguish the degree of substitution between trade credit and bank credit for firms that obtain funds from just one bank (DBank) and those doing so from several banks, we introduce in model (4) (for both samples) the variable $\mathrm{DBank}_{1} * \mathrm{BC}_{1}$. The substitution hypothesis has been confirmed; the coefficient of the variable $\mathrm{DBank}_{1} * \mathrm{BC}_{1}$ is negative and statically significant when firms maintain a link with just one bank. Besides the fact that for Portuguese samples the variable Bank Credit ${ }_{1}$ reverts the signal when the variable $\mathrm{DBank}_{1} * \mathrm{BC}_{1}$ is introduced, the empirical evidence points to a relation of substitution between trade credit and bank credit, which may indicate the existence of rationing by financial institutions. Furthermore, a greater degree of substitution is obtained by firms working with one bank. This result seems to indicate that such firms

\footnotetext{
${ }^{20}$ Wilner (2000) argues that the higher trade credit interest rate is fair compensation for suppliers due to the large renegotiation concessions they grant to their customers, especially if financial distress occurs from their customers.

${ }^{21}$ It is well known that the establishment of a relationship between moneylender and borrower is a way of reducing the problems of asymmetric information (Leland and Pyle, 1977; Diamond, 1984, 1991; Rajan, 1992; Boot and Thakor, 2000). Nevertheless, maintaining a loan relationship with only one financial institution may also convey some disadvantages (Detragiache et al., 2000; Sharpe, 1990). In fact, companies that borrow from just one financial intermediary are "informationally captured", as no one else knows the real risk of the firm. In these circumstances, the monopolistic relationship may be exploited in order to charge a greater interest rate on new loans or even to ration additional borrowing.
} 
are subject to a greater monopoly by the financial institutions, which impedes their obtaining alternative financing apart from that of their trade credit suppliers ${ }^{22}$.

\subsection{The effect of the strength banking relationship on the availability of bank credit}

The results described in the previous section appear to indicate that those firms with a higher degree of substitution between bank credit and trade credit are ones that immerse in a more asymmetric environment. In fact, it could be argued that small firms basically have only two sources of external finance: trade credit and bank credit, because these firms do not have access to the capital markets.

Indeed the situation is more complex. In recent years, the banking industry has experimented modifications and restructurings and also faced regulatory (the single market program in the European Union, The Gramm-Leach-Bliley Act in the U.S., the Basel II agreement) and technological changes that might affect the aggregate amount of credit supplied to the economy as well as the composition of banks credit portfolios (Degryse and Ongena, 2007; Petersen and Rajan, 1994). Small business firms may be particularly affected by these changes because of their dependency of financial institutions for external finance (Berger and Udell, 1995; Berger et al., 2001; Berger et al., 2001). Large banking institutions devote lesser proportions of their assets to SME, suggesting that consolidation in the financial system reduce the availability of credit to SME (Anand and Galetovic, 2006; Berger et al., 2005; Berger et al., 2007; Berger and Udell, 2002; Degryse and Ongena, 2007; Graig and Hardee, 2007). The financial distress in the banking industry may also impact lending to SME. In order to reduce their risk exposure, banks can ration SME credit and develop a politic of arm's length debt (Berger and Udell, 2002; Boot and Thakor, 2000; Karceski, et al., 2005).

It is well-known that banks elevate the interest rate as the borrower increases the demand for funds. High interest rates will encourage the debtor to choose projects with a greater risk because it now has to assume greater financial expenses (Myers, 1977; Stiglitz and Weiss, 1981).

\footnotetext{
22 This monopolist effects is reinforced because when we substitute the variable $\mathrm{Dbank}_{1} * \mathrm{BC}_{1}$, by the variable Dbank $_{2} * \mathrm{BC}_{1}$, the coefficient reserves the signal (positive) and is statistically significant.
} 
In a context of asymmetric information, an increase in risk is too expensive, consequently some financial institutions may prefer to restrict the loans they give before they increase their interest rate. Therefore, the credit availability will increase with the interest rate until it reaches a maximum. Furthermore banks have incentive for establishing this maximum so that the market stays in a rationing situation.

Because this credit rationing appears particularly harmful for SME, we intend now to analyse if information conveyed by trade credit could affect the level of the indebtnees of the small firms. In order to do so we examine the nexus between the level of bank debt and interest rate. The goal is tested if financial institutions price the debt they lend to the small firms, considering the strength of their relationship (see footnote 21). This point is important based on results obtained for model 4, table II: firms that indebt with fewer financial institutions are more likely to be subject to monopolist conditions.

To contrast this point the two samples were divided into companies that obtain funds from just one bank than those that obtain funds from several banks. The samples were organized according to the number of banks the firms had worked with in 2006. In this way the Portuguese and Spanish samples were reduced to 110 and 2471 firms, respectively.

The following regression is proposed:

$$
\mathrm{BC}_{\mathrm{it}}=\alpha_{0}+\beta_{1} T C_{i t}+\beta_{2} \text { Interest }_{i t}+\sum_{j=1}^{J} \delta_{j} X_{i j}+\eta_{i}+\lambda_{t}+\varepsilon_{i t}
$$

Where bank credit (BC) has been measured with the ratio of bank debt to total assets, trade credit (TC) is the ratio of the difference between debtors and creditors to total assets and interest is the ratio of financial expenses to total bank debt. Regarding control variables, it is reasonable to consider: i) size, ii) age; iii) profitability, iv) tangibility, v) coverage and vi) Altman Z-Score, variables which are taken into account by banks when they lend and pricing loans (see for example: Petersen and Rajan, 1994; Berger and Udell, 1995; Bonfim et al., 2008 and Canovas and Solano, 2006). In order to control for the possibility of non-linear relation as suggested by Stiglitz and Weiss 
(1981), the variable interest is also included in quadratic form. ${ }^{23}$ The results are reported in Table III.

Analysing the results presented in table III, we observe that the variable trade credit (TC) is negative and statically significant for Spanish firms, in all models, which confirms the substitution relation between bank credit and trade credit. Curiously, for Portuguese firms we obtain an opposite result. When we concentrate our analysis in variables Interest and Interest* ${ }^{*}$ bank $_{1}$ (model 1) for both samples, it is not clear that the firms that borrow from just one bank are more financially restricted (the coefficient for both variables is negative). However, as it can be observed in model (1) the coefficient of the variable Interest $^{2}$ is not statically significant, which indicates that the nonlinearity is not a problem. To control the existence of non-quadric performance and also to reduce potential problems of multicollinearity between the variable Interest and Interest $^{2}$, a linear model was also set up in equation (2) of table III. A positive coefficient was obtained for the variable Interest* ${ }^{*} b_{a n k}$ for Portuguese samples which indicate that these firms are more financially restricted and, therefore, obtain the same amount of bank fund but facing an increases interest rate. For Spanish firms the results are more in ambiguous, both variable Interest and Interest* Dbank ${ }_{1}$ are not statistically significant. $^{24}$

\footnotetext{
${ }^{23}$ It could be argued that bank credit and interest rate are also endogenous variables. Using GMM estimators and lagged variables in the estimation of the models help to control for this hypothetic problem.

${ }^{24}$ Lehmann and Newberger (2001) argue that if any inefficient allocation of resources reduces the benefits, the bank losses will be paid by the clients who maintain a relationship with a bank.
} 
TABLE III

The effect of the strength banking relationship on availability of bank credit

\begin{tabular}{|c|c|c|c|c|c|c|c|c|}
\hline & \multicolumn{4}{|c|}{ Spain } & \multicolumn{4}{|c|}{ Portugal } \\
\hline & $\begin{array}{l}\text { Regression Bank } \\
\text { Credit (1) }\end{array}$ & $\begin{array}{c}\text { Regression Bank } \\
\text { Credit (2) }\end{array}$ & $\begin{array}{c}\text { Regression Bank } \\
\text { Credit (3) }\end{array}$ & $\begin{array}{l}\text { Regression Bank } \\
\text { Credit (4) }\end{array}$ & $\begin{array}{c}\text { Regression Bank } \\
\text { Credit (1) }\end{array}$ & $\begin{array}{l}\text { Regression Bank } \\
\text { Credit (2) }\end{array}$ & $\begin{array}{c}\text { Regression Bank } \\
\text { Credit (3) }\end{array}$ & $\begin{array}{c}\text { Regression } \\
\text { Bank Credit (4) }\end{array}$ \\
\hline Trade Credit & $\begin{array}{c}-0.079^{3 * 39} \\
(-4.845)\end{array}$ & $\begin{array}{c}-0.078^{* * * 3} \\
(-3.710)\end{array}$ & $\begin{array}{c}-0.085^{* 3 * 2} \\
(-3.568)\end{array}$ & $\begin{array}{c}-0.082^{* * * 37} \\
(-3.857)\end{array}$ & $\begin{array}{l}0.198^{\text {*3*3* }} \\
(2.954)\end{array}$ & $\begin{array}{l}0.067^{* 3 * 3} \\
(10.264)\end{array}$ & $\begin{array}{l}0.123^{* * F} \\
(2.270)\end{array}$ & $\begin{array}{l}0.093^{* * 39} \\
(10.141)\end{array}$ \\
\hline Interest & $-0.001^{*}$ & $\begin{array}{c}-0.000 \\
(-1240)\end{array}$ & $\begin{array}{l}-0.006^{* * *} \\
(-4320)\end{array}$ & $\begin{array}{l}-0.000 \\
(-1237)\end{array}$ & $\begin{array}{l}-0.190^{* * * *} \\
(-3755)\end{array}$ & $\begin{array}{l}-0.128^{* * * *} \\
(-67071)\end{array}$ & $\begin{array}{l}-0.775^{* * * *} \\
(-3.535)\end{array}$ & $\begin{array}{l}-0.056^{* * * *} \\
(-68114)\end{array}$ \\
\hline Interest x Dbank1 & $\begin{array}{l}-0.007^{* * * *} \\
(-4.151)\end{array}$ & $\begin{array}{l}-0.000 \\
(-1.279)\end{array}$ & --------- & - & $\begin{array}{l}-0.768^{* * *} \\
(-2.569)\end{array}$ & $\begin{array}{l}0.077^{* * * *} \\
(47.627)\end{array}$ & ---------- & ---------- \\
\hline Interest x Dbank2 & ---------- & ---------- & $\begin{array}{c}0.006^{* * *} \\
(3.831)\end{array}$ & $\begin{array}{c}-0.002^{* * *} \\
(-3.055)\end{array}$ & --------- & (19.0. & $\begin{array}{l}0.688^{* * *} \\
(2.672)\end{array}$ & $\begin{array}{l}-0.050^{* * * *} \\
(-27.370)\end{array}$ \\
\hline Interest $^{2}$ & $\begin{array}{l}0.000 \\
(1.087)\end{array}$ & --------- & $\begin{array}{l}0.000^{* * * *} \\
(4.237)\end{array}$ & & $\begin{array}{c}0.021 \\
(1.386)\end{array}$ & & $\begin{array}{l}0.064^{* * * *} \\
(3.315)\end{array}$ & \\
\hline Interest ${ }^{2} \mathrm{x}$ Dbank1 & $\begin{array}{l}0.000^{* * * * *} \\
(4.504)\end{array}$ & ---------- & ---------- & ---------- & $\begin{array}{l}0.058^{*} \\
(1.739)\end{array}$ & --------- & ---------- & --------- \\
\hline Interest $^{2} \mathrm{x}$ Dbank2 & ---------- & ---------- & $\begin{array}{l}-0.000^{* * * *} \\
(-4.222)\end{array}$ & ---------- & ----------- & ---------- & $\begin{array}{l}-0.083^{* * *} \\
(-2.700)\end{array}$ & ---------- \\
\hline Size & $\begin{array}{l}0.099^{* * *} \\
(14.648)\end{array}$ & $\begin{array}{l}0.098^{* * *} \\
(7.244)\end{array}$ & $\begin{array}{l}0.098^{* * * *} \\
(8.238)\end{array}$ & $\begin{array}{c}0.097^{* * * *} \\
(7.156)\end{array}$ & $\begin{array}{c}-0.050^{* * * *} \\
(-4.827)\end{array}$ & $\begin{array}{l}-0.047^{* * * *} \\
(-18.643)\end{array}$ & $\begin{array}{l}-0.042^{* * * *} \\
(-6.266)\end{array}$ & $\begin{array}{l}-0.049^{* * * *} \\
(-18.912)\end{array}$ \\
\hline Age & $\begin{array}{l}-0.115^{* * *} \\
(-11.167)\end{array}$ & $\begin{array}{l}-0.114^{* * *} \\
(-9.408)\end{array}$ & $\begin{array}{l}-0.111^{* * * *} \\
(-6.762)\end{array}$ & $\begin{array}{l}-0.110^{* * * *} \\
(-8.910)\end{array}$ & $\begin{array}{l}0.001^{* * * *} \\
(0.040)\end{array}$ & $\begin{array}{l}0.031^{\text {**** }} \\
(8.308)\end{array}$ & $\begin{array}{c}0.008 \\
(0.267)\end{array}$ & $\begin{array}{l}0.031^{* * * *} \\
(8.258)\end{array}$ \\
\hline Profitability & $\begin{array}{l}0.986^{* * * *} \\
(12.747)\end{array}$ & $\begin{array}{l}1.017^{* * * *} \\
(4.524)\end{array}$ & $\begin{array}{l}1.012^{* * * *} \\
(4.107)\end{array}$ & $\begin{array}{l}1.031^{\text {**** }} \\
(4.612)\end{array}$ & $\begin{array}{l}0.558^{* * *} \\
(3.055)\end{array}$ & $\begin{array}{l}0.562^{* * *} \\
(59.089)\end{array}$ & $\begin{array}{c}0.640^{\text {**** }} \\
(3.894)\end{array}$ & $\begin{array}{l}0.581^{\text {**** }} \\
(32.182)\end{array}$ \\
\hline Tangible & $\begin{array}{l}0.204^{* * * *} \\
(14.371)\end{array}$ & $\begin{array}{l}0.206^{* * *} \\
(10.324)\end{array}$ & $\begin{array}{l}0.198^{* * *} \\
(8.802)\end{array}$ & $\begin{array}{l}0.199^{* * *} \\
(10.000)\end{array}$ & $\begin{array}{l}-0.148^{* * * *} \\
(-2.884)\end{array}$ & $\begin{array}{l}-0.067^{* * *} \\
(-12.687)\end{array}$ & $\begin{array}{l}-0.221^{* * * *} \\
(-4.250)\end{array}$ & $\begin{array}{l}-0.063^{* * *} \\
(-11.867)\end{array}$ \\
\hline Coverage & $\begin{array}{c}-0.000^{* * *} \\
(-6.780)\end{array}$ & $\begin{array}{l}-0.000^{*} \\
(-1.877)\end{array}$ & $\begin{array}{l}-0.000 \\
(-1.474)\end{array}$ & $\begin{array}{l}-0.000^{*} \\
(-1.680)\end{array}$ & $\begin{array}{c}-0.000^{* * * *} \\
(-3.117)\end{array}$ & $\begin{array}{l}-0.000^{* * * *} \\
(-15.568)\end{array}$ & $\begin{array}{l}-0.000^{* * * *} \\
(-4.353)\end{array}$ & $\begin{array}{l}-0.000^{* * * *} \\
(-14.595)\end{array}$ \\
\hline Altman Z-score & $\begin{array}{l}-0.014^{* * * *} \\
(-3.032)\end{array}$ & $\begin{array}{l}-0.015^{*} \\
(-1.778)\end{array}$ & $\begin{array}{l}-0.016^{*} \\
(-2.102)\end{array}$ & $\begin{array}{l}-0.019^{*} \\
(-2.158)\end{array}$ & $\begin{array}{l}-0.169^{\text {**** }} \\
(-11.249)\end{array}$ & $\begin{array}{l}-0.160^{* * * *} \\
(-108.764)\end{array}$ & $\begin{array}{l}-0.166^{* * *} \\
(-10.904)\end{array}$ & $\begin{array}{l}-0.165^{\text {**** }} \\
(-74.948)\end{array}$ \\
\hline Constant & $\begin{array}{c}-0.165^{* * *} \\
(-3.304)\end{array}$ & $\begin{array}{c}-0.160^{*} \\
(-1.760)\end{array}$ & $\begin{array}{l}-0.162^{*} \\
(-1.872)\end{array}$ & $\begin{array}{l}-0.150^{*} \\
(-1.653)\end{array}$ & $\begin{array}{l}1.160^{* * * *} \\
(16.654)\end{array}$ & $\begin{array}{l}0.984^{* * *} \\
(58.237)\end{array}$ & $\begin{array}{l}1.135^{* * *} \\
(16.007)\end{array}$ & $\begin{array}{l}1.003^{* * *} \\
(56.276)\end{array}$ \\
\hline Sargan Test & 0,989 & 0.976 & 0.981 & 0.963 & 0.997 & 0.995 & 0.997 & 0.992 \\
\hline Hausman Test $\left(\chi^{2}\right)$ & 187.419 & 115.885 & 123.277 & 115.885 & 37.842 & 12.572 & 45.512 & 12.435 \\
\hline
\end{tabular}

1- All regressions are estimated by using GMM, which are robust to the heterocedasticity. Sargan Test, tests of absence of over identification. T-Statistic are in parentheses.

2- According to the Hausman Test, the bank credit models for the Spanish sample are estimated by fixed - effects; for Portuguese sample the estimation is based on random effects.

3- Bank credit, which is proxied with the ratio of bank debt to total assets is the dependent variable. Dbank is a dummy variable that takes the value one if the firm works with just one bank (or two banks) in the

regressions 1 and 2 (3 and 4) and zero otherwise. Interest is the ratio of financial expenses to total debt. For other variables, see definition in appendix I.

**** Significant at $1 \% ;{ }^{* * *}$ Significant at $5 \% ;{ }^{*}$ Significant at $10 \%$. 
According to Von Thadden (1994), borrowing from just two banks is sufficient to eliminate the negative aspect of aspects of a monopolistic relationship (e.g. the asymmetric evolution of the information between the bank and other lenders allow the bank to extract monopoly rents from the relationship), while it enables the company to enjoy the advantage of the relationship with each bank. In this way we introduce in model (3), table III the dummy variable Dbank ${ }_{2}$, which takes the value one if the firm maintains a relationship with two banks. As is shown in regression (3), for both of samples the concave relation (the coefficient of the variable Interest $*$ Dbank $_{2}$ is negative and statistically significant) holds for firms working with one or two banks. When the variables Interest ${ }^{2}$ and Interst ${ }^{2} *$ Dbank $_{2}$ were removed from the model, the result reported by the variable Interest* Dbank $_{2}$ seems to indicate that firms who work with two banks can obtain credit in more advantage conditions. These results are consistent with the ones in the previous section, indicating that the problem of adverse selection is much stronger for firms that work with less than three financial intermediaries. This is particularly relevant in our samples: more than fifty percent of small young firms maintain a relationship with just one bank (in our samples, the maximum number of banks that Spanish and Portuguese firms work with is 7 and 6 banks respectively).

These results are in accordance with Degryse and Ongena (2007). These authors show that in several European countries, especially firms in countries characterized by European continental civil-low model, such as France, Italy, Spain and Portugal, the cost of bank loans is either unaffected by 1 to 10 bases point per additional relationship, while in the U.S. the cost of bank loans typically increases with the number of bank relationships. These opposite results may be explained by the degree of disintermediation of the economies and therefore in companies`access to alternatives sources of financing.

For the control variables, the results obtained for Spanish sample (models 1, 2, 3 and 4) confirm our expectations: large and older companies have a greater access to bank financing. Bank credit also increase for more profitable firms, firms with more capacity to pledge of collateral and less riskier firms [the mean of the variable Altman Z-Score is 3,5 and 2,2 for Spanish and Portuguese SME respectively, values that could be considered in the range of uncertainty of default risk (Neves, 2006:215)]. Regarding the 
Portuguese sample the results are quite different. Older and more profitable firms obtain higher levels of bank credit, whereas small firms are more credit constrained.

Assuming that the size of the borrower is an inverse measure of its information opaqueness (the coefficient of the variable size is negative and statistically significant) and the age of the firms reflects the public reputation that is openly transmitted to the market (the coefficient of the variable age is positive and statically significant), it is reasonable to conclude that Portuguese banks avoid to support the fixed cost of screening and monitoring SME. In this context, and based on the result obtained for the variable trade credit (the coefficient is positive and statistically significant), we could argue that trade credit could act as a signal of firm's quality and help young firms to build a "good reputation" in the borrower market at low cost (the results of the model (3) in table II, also confirms a positive relationship between more younger firms with trade credit). Trade credit could mitigate the information asymmetry; assuming that trade credit reveals the private information of the supplier to the bank, which, in turn, can update its beliefs about customer default risk (Biais and Gollier, 1997). The illiquidity of trade credit also prevents opportunistic borrowers to divert cash (Burkart and Ellingsen, 2004).

\section{Conclusion}

Previous research implicitly assumes that the use of trade credit is at least partially the result of credit rationing, and is a very expensive source of funds when discounts for early payment are not taken (Petersen and Rajan, 1997).

Using a panel data from a representative sample of Spanish and Portuguese SME operating in Manufacturing of Foods and Beverages (NACE codes 15 and 16), this study focuses on the question: Why is trade credit available when banking credit is rationed? With this aim we test: first if trade credit could be considered as a substitute and/or a complement to bank credit, in order to assess the existence of credit rationing, second if the availability of trade credit facilitates the access to bank credit, especially for young firms, by improving their reputation on borrower market. 
Related to the first issue, our results indicate the existence of credit rationing among Spanish and Portuguese SME, since the substitution hypothesis between trade and bank credit is confirmed. Particularly, firms that maintain an exclusive relationship with one bank report a higher degree of substitution between both sources of financing, which indicate the greater severity of adverse selection problem in those companies. This monopolistic relationship puts the informed bank in a position to exert market power, which could impose hold-up costs for the firm, the soft-budge constrain problem is more likely to happen because the lender has the option to bail out the firm in case of distress. The establishment of relationships with more than one bank, as suggested by Von Thadden (1994) and Degryse and Ongena (2007), could reduce such exploitation, as confirmed by our result.

Nevertheless the fact that the substitution hypothesis is confirmed, our empirical results seem to indicate that the substitution and complementary hypothesis are not mutually exclusives, if we take into account a specific class of firms the younger and smaller firms. In fact, small and young firms have not yet been able to establish a reputation, so banks do not have any information about the competence and honesty of managers, nor about the type of projects that may arise. These elevate the cost of production of information and the fixed costs of screening and monitoring such firms.

Notwithstanding, suppliers have a monitoring advantage over banks. Suppliers obtain information about the borrower routinely and at low cost, from their transaction with the firm. The most valuable aspect of this information may be how current it is. By monitoring repayment and using discounts as trip wire, suppliers get easy information on firm's financial and economic health. This informative advantage allows suppliers to provide financial support better than banks do, when firms are small, young and opaque (Wilner, 2000). Our empirical evidence for the variable age, and agree with Berger and Udell $(1995,1998)$, confirms that the variable age is positively related with trade credit for infant and adolescent firms. This positive relationship, and in line with the theories which emphasize the informational role of trade credit (Biais and Gollier, 1997), could be explained because trace credit helps to solve principal agent problems of managerial behaviour, due to the lack of separation between ownership and management in more younger and smaller firms. The illiquidity of trade credit also facilitates borrowing by limiting the borrower's discretion (Burkart and Ellingsen, 2004). In that way trade 
credit stimulates small firms to improve their reputation, as it acts as a signal about firm's quality, than facilitates access to bank debt.

This study focuses on the signalling role of trade credit, a topic that is still not yet very explored in the literature, however more attention should be given to the price discrimination aspect of trade credit and the influence of trade discount policy. Finally, further research should investigate how the interaction between information motivated bank credit rationing and trade credit varies with the business cycle; how this affects the conduct of monetary policy and how trade credit, by generating a chain of bankruptcies can have a feedback effect on the economic development (see Guedes and Mateus, 2008). 


\section{APPENDIXIES}

\section{APPENDIX I}

Trade Credit $(\mathrm{TC})=\frac{\text { Debtors }- \text { Creditors }}{\text { Total Assets }}$

Bank Credit $_{1}\left(\mathrm{BC}_{1}\right)=\frac{\text { Total Debt }}{\text { Total Assets }}$

Bank Credit $_{2}\left(\mathrm{BC}_{2}\right)=\frac{\text { Short term Debt }}{\text { Total Liabilities }}$

Bank Credit ${ }_{3}\left(\mathrm{BC}_{3}\right)=\frac{\text { Long Term Debt }}{\text { Total Liabilities }}$

Size $=$ Ln $($ Total Assets $)$

Asset Structure $=\frac{\text { Current Assets }- \text { Cash }}{\text { Total Assets }}$

Age $=$ Ln (time elapsed between the firm's founding date and the year of measurement)

Accounts Turnover $=\frac{\text { Sales }}{\text { Current Assets }}$

Liquidity $=\frac{\text { Current Assets }- \text { Stocks }}{\text { Current Liabilities }}$

Inventory Turnover $=\frac{\text { Net Sales }}{\text { Stocks }}$

Sales Growth $=\left(\frac{\text { Sales }(t+1)}{\text { Sales }(t)}\right)-1$

Profitability $=\frac{E B I T^{*}}{\text { Total Assets }}$

*EBIT - Earning Before Interest and Taxes

Interest $=\frac{\text { Financial Expenses }}{\text { Total Bank Debt }}$

Interest $^{2}=(\text { Interest })^{2}$

Debt Coverage $=\frac{\text { Net } \operatorname{Pr} \text { oft }}{\text { Interest Expenses }}$

Altman Z-Score $=1.2$ [working capital $/$ Total Assets $]+1.4[$ retained earnings $/$ Total Assets $]+3.3$ [EBIT / Total Assets] + 0.6 [Capital / Total Liabilities] + 1 [sales / Total Assets]

Tangibility $=\frac{\text { Tangible Fixed Assets }}{\text { Total Assets }}$

DBank1 = Dummy that takes value 1 if the company works with just one bank and 0 in the opposite case.

DBank2 = Dummy that takes value 1 if the company works with two banks and 0 in the opposite case. 


\section{APPENDIX II}

\section{Descriptive Statistics - Spain ${ }^{1}$}

\begin{tabular}{|c|c|c|c|c|c|c|c|c|c|c|c|c|c|c|c|c|c|c|c|}
\hline & 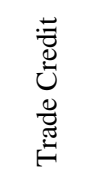 & 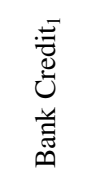 & 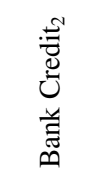 & 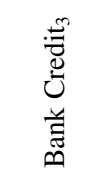 & $\stackrel{\tilde{N}}{\tilde{n}}$ & 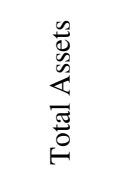 & $\stackrel{8}{8}$ & 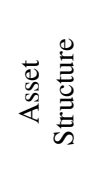 & 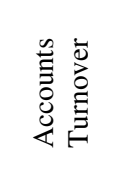 & $\stackrel{\overparen{\Xi}}{:}$ & 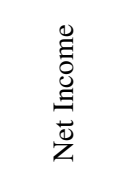 & 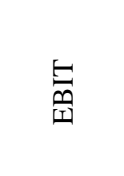 & 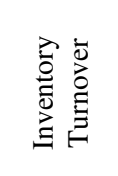 & 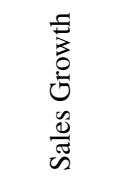 & $\begin{array}{l}\overrightarrow{\breve{s}} \\
\stackrel{\vec{U}}{\Xi}\end{array}$ & 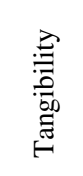 & ن & 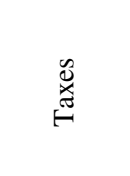 & 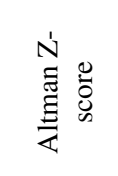 \\
\hline Mean & 0.207 & 0.294 & 0.231 & 0.005 & 5.862 & 931.079 & 11.484 & 0.409 & 5.552 & 2.892 & 20.340 & 37.462 & 54.900 & 7.486 & 0.740 & 0.406 & 0.037 & 10.616 & 3.549 \\
\hline Median & 0.155 & 0.237 & 0.154 & 0.000 & 5.849 & 346.908 & 11.000 & 0.385 & 2.838 & 0.663 & 4.604 & 9.855 & 10.426 & 0.025 & 0.072 & 0.394 & 0.021 & 1.139 & 2.470 \\
\hline Maximum & 1.000 & 1.000 & 16.594 & 0.895 & 11.034 & 61949.86 & 25.000 & 1.000 & 11997.40 & 5420.667 & 9717.320 & 9831.599 & 154964.1 & 287953.0 & 7243.000 & 1.000 & 172.667 & 3041.033 & 4881.597 \\
\hline Minimum & -1.849 & 0.000 & 0.000 & 0.000 & -5.298 & 0.000 & 1.000 & -0.000 & 0.000 & 0.000 & -6230.856 & -5614.930 & 0.000 & -1.000 & -2.699 & 0.000 & -0.807 & -1141.831 & -3508.034 \\
\hline Std. Dev & 0.193 & 0.274 & 0.291 & 0.045 & 1.402 & 2005.516 & 6.032 & 0.250 & 78.697 & 56.142 & 158.142 & 187.935 & 914.255 & 1392.981 & 43.092 & 0.251 & 0.898 & 59.818 & 39.277 \\
\hline Skewness & 1.145 & $0 . .665$ & 12.657 & 9.828 & -0.046 & 7.670 & 0.281 & 0.341 & 111.906 & 63.791 & 15.065 & 13.787 & 133.647 & 206.651 & 153.915 & 0.187 & 177.200 & 19.798 & 44.723 \\
\hline Kurtosis & 4.939 & 2.383 & 575.402 & 109.735 & 3.341 & 104.906 & 2.243 & 2.172 & 14717.02 & 4715.598 & 911.603 & 576.361 & 21452.26 & 42717.54 & 25448.81 & 2.052 & 33306.05 & 755.601 & 7751.267 \\
\hline
\end{tabular}

${ }^{\mathrm{T}}$ For definition of the variables see appendix I. All variables are measured in thousand of Euros, except ratios. 


\section{APPENDIX III}

\section{Descriptive Statistics - Portugal ${ }^{1}$}

\begin{tabular}{|c|c|c|c|c|c|c|c|c|c|c|c|c|c|c|c|c|c|c|c|}
\hline & 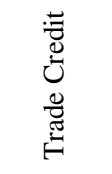 & 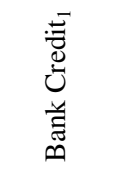 & 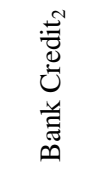 & 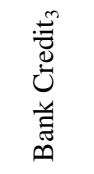 & $\stackrel{\tilde{N}}{\tilde{S}}$ & 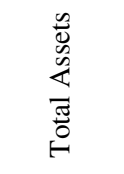 & $\stackrel{8}{\&}$ & 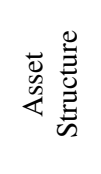 & 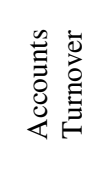 & 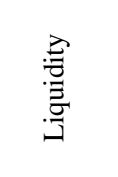 & 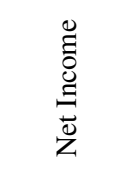 & $\stackrel{\Xi}{\stackrel{9}{I I}}$ & 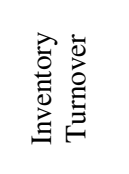 & $\frac{\mathscr{s}}{\tilde{N}}$ & 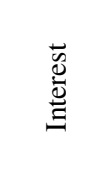 & 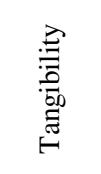 & 泀苛 & 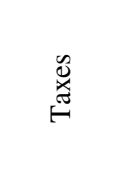 & 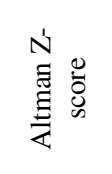 \\
\hline Mean & 0.268 & 0.401 & 0.093 & 0.114 & 5.618 & 1767.319 & 8.000 & 0.395 & 3.990 & 1.501 & 18.349 & 44.327 & 63.095 & 2.059 & 0.367 & 0.467 & 0.028 & 13.591 & 2.209 \\
\hline Median & 0.137 & 0.267 & 0.000 & 0.000 & 4.960 & 142.417 & 6.000 & 0.362 & 2.884 & 0.603 & 2.416 & 2.838 & 13.912 & 0.059 & 0.063 & 0.460 & 0.019 & 0.271 & 1.984 \\
\hline Maximum & 9.901 & 24.565 & 2.190 & 0.996 & 10.517 & 36925.27 & 25.000 & 5.668 & 137.127 & 705.033 & 2273.518 & 2240.456 & 4448.667 & 275.924 & 52.067 & 3.275 & 0.845 & 697.507 & 295.276 \\
\hline Std. Dev & 0.794 & 1.018 & 0.181 & 0.200 & 2.028 & 3841.455 & 5.901 & 0.280 & 5.696 & 18.542 & 210.5540 & 235.814 & 241.954 & 16.741 & 2.617 & 0.260 & 0.051 & 48.944 & 8.217 \\
\hline Skewness & -15.753 & 20.480 & 3.422 & 1.955 & 0.369 & 4.310 & 1.301 & 4.774 & 10.953 & 37.416 & -0.006 & 2.518 & 10.867 & 12.314 & 13.868 & 0.851 & 7.893 & 6.427 & 30.674 \\
\hline Kurtosis & 544.960 & 483.417 & 22.757 & 6.016 & 2.226 & 28.325 & 3.618 & 86.733 & 225.399 & 1419.584 & 63.983 & 30.997 & 154.435 & 172.398 & 225.107 & 11.220 & 91.386 & 59.635 & 1103.888 \\
\hline
\end{tabular}

${ }^{1}$ For definition of the variables see appendix I. All variables are measured in thousand of Euros, except ratios. 


\section{APPENDIX IV}

Matrix of correlations - Spain ${ }^{1}$

\begin{tabular}{|c|c|c|c|c|c|c|c|c|c|c|c|c|c|c|c|}
\hline 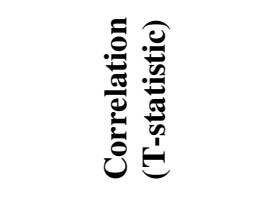 & 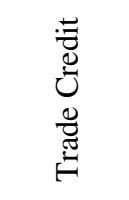 & 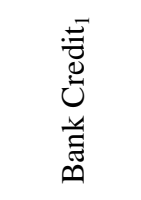 & 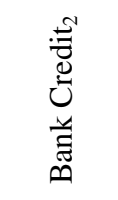 & $\stackrel{\tilde{N}}{i s}$ & 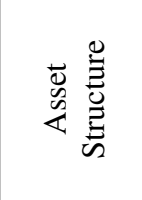 & $\sum_{i}^{\infty}$ & 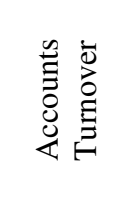 & : & 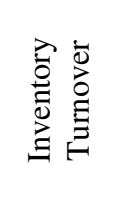 & 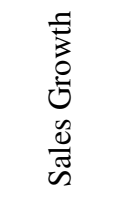 & 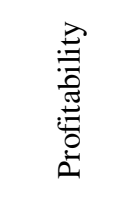 & $\begin{array}{l}\breve{0} \\
\stackrel{0}{0} \\
\stackrel{0}{\Xi}\end{array}$ & 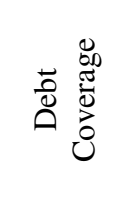 & 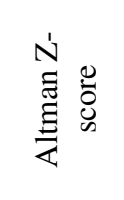 & 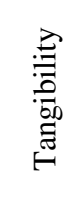 \\
\hline Trade Credit & 1.000 & & & & & & & & & & & & & & \\
\hline Bank Credit $_{1}$ & $\begin{array}{l}-0.135^{* * * *} \\
(-28.559)\end{array}$ & 1.000 & & & & & & & & & & & & & \\
\hline Bank Credit $_{2}$ & $\begin{array}{l}-0.084^{* * * *} \\
(-17.478)\end{array}$ & $\begin{array}{l}0.099^{* * * *} \\
(20.960)\end{array}$ & 1.000 & & & & & & & & & & & & \\
\hline Size & $\begin{array}{l}0.141^{* * * *} \\
(29.826)\end{array}$ & $\begin{array}{l}0.161^{* * *} \\
(34.061)\end{array}$ & $\begin{array}{l}0.247^{* * * *} \\
(53.095)\end{array}$ & 1.000 & & & & & & & & & & & \\
\hline Asset Structure & $\begin{array}{c}0.617^{* * * *} \\
(163.718)\end{array}$ & $\begin{array}{l}-0.180^{* * *} \\
(-38.314)\end{array}$ & $\begin{array}{l}0.084^{* * *} \\
(17.507)\end{array}$ & $\begin{array}{l}0.154^{* * * *} \\
(32.527)\end{array}$ & 1.000 & & & & & & & & & & \\
\hline Age & $\begin{array}{l}0.052^{* * *} \\
(10.751)\end{array}$ & $\begin{array}{l}-0.093^{* * * *} \\
(-19.282)\end{array}$ & $\begin{array}{l}0.104^{* * * *} \\
(21.630)\end{array}$ & $\begin{array}{c}0.260^{* * * *} \\
(55.540)\end{array}$ & $\begin{array}{l}0.115^{* * *} \\
(23.818)\end{array}$ & 1.000 & & & & & & & & & \\
\hline Accounts Turnover & $\begin{array}{l}-0.179^{* * * *} \\
(-37.574)\end{array}$ & $\begin{array}{c}-0.028^{* * * *} \\
(-5.754)\end{array}$ & $\begin{array}{c}-0.024^{* * * *} \\
(-4.959)\end{array}$ & $\begin{array}{l}-0.420^{* * * *} \\
(-95.595)\end{array}$ & $\begin{array}{l}-0.384^{* * * *} \\
(-85.905)\end{array}$ & $\begin{array}{l}-0.0515^{* * * *} \\
(-10.652)\end{array}$ & 1.000 & & & & & & & & \\
\hline Liquidity & $\begin{array}{c}0.391^{* * * *} \\
(88.553)\end{array}$ & $\begin{array}{c}-0.039^{* * * *} \\
(-8.145)\end{array}$ & $\begin{array}{l}0.017^{* * * *} \\
(3.589)\end{array}$ & $\begin{array}{c}0.040^{* * * * *} \\
(8.319)\end{array}$ & $\begin{array}{c}0.040^{* * * *} \\
(8.424)\end{array}$ & $\begin{array}{l}0.153^{* * * *} \\
(31.987)\end{array}$ & $\begin{array}{l}-0.122^{* * *} \\
(-25.412)\end{array}$ & 1.000 & & & & & & & \\
\hline Inventory Turnover & $\begin{array}{l}0.126^{* * * *} \\
(25.218)\end{array}$ & $\begin{array}{l}-0.052^{* * *} \\
(-10.341)\end{array}$ & $\begin{array}{l}-0.004 \\
(-0.708)\end{array}$ & $\begin{array}{l}-0.256^{* * *} \\
(-52.684)\end{array}$ & $\begin{array}{l}-0.439^{* * * *} \\
(-97.135)\end{array}$ & $\begin{array}{l}-0.016^{* * *} \\
(-3.204)\end{array}$ & $\begin{array}{c}0.696^{* * *} \\
(192.599)\end{array}$ & $\begin{array}{l}0.330^{* * *} \\
(69.320)\end{array}$ & 1.000 & & & & & & \\
\hline Sales Growth & $\begin{array}{l}0.023^{* * * *} \\
(4.421)\end{array}$ & $\begin{array}{l}0.081^{* * * *} \\
(15.560)\end{array}$ & $\begin{array}{l}0.017^{* * * *} \\
(3.248)\end{array}$ & $\begin{array}{c}0.097^{* * * *} \\
(18.813)\end{array}$ & $\begin{array}{l}0.031^{* * * *} \\
(-5.909)\end{array}$ & $\begin{array}{l}-0.163^{* * * *} \\
(-31.622)\end{array}$ & $\begin{array}{l}0.064^{* * *} \\
(12.208)\end{array}$ & $\begin{array}{c}-0.035^{* * *} \\
(-6.716)\end{array}$ & $\begin{array}{l}0.061^{* * * *} \\
(11.325)\end{array}$ & 1.000 & & & & & \\
\hline Profitability & $\begin{array}{l}0.069^{* * * *} \\
(14.428)\end{array}$ & $\begin{array}{l}-0.089^{* * * *} \\
(-18.674)\end{array}$ & $\begin{array}{l}0.032^{* * * *} \\
(6.745)\end{array}$ & $\begin{array}{l}-0.009^{*} \\
(-1.939)\end{array}$ & $\begin{array}{c}0.003 \\
(0.709)\end{array}$ & $\begin{array}{c}0.055^{* * * *} \\
(11.399)\end{array}$ & $\begin{array}{l}0.197^{* * *} \\
(41.558)\end{array}$ & $\begin{array}{l}0.282^{* * * *} \\
(61.180)\end{array}$ & $\begin{array}{l}0.273^{* * * *} \\
(56.333)\end{array}$ & $\begin{array}{l}0.147^{* * *} \\
(28.454)\end{array}$ & 1.000 & & & & \\
\hline Interest & $\begin{array}{l}0.231^{* * * *} \\
(42.168)\end{array}$ & $\begin{array}{c}-0.562^{* * * *} \\
(-120.696)\end{array}$ & $\begin{array}{l}-0.052^{* * * *} \\
(-9.148)\end{array}$ & $\begin{array}{l}0.023^{* * * *} \\
(4.056)\end{array}$ & $\begin{array}{l}0.288^{* * * *} \\
(53.449)\end{array}$ & $\begin{array}{l}0.114^{* * * *} \\
(20.155)\end{array}$ & $\begin{array}{l}0.094^{* * * * *} \\
(16.656)\end{array}$ & $\begin{array}{l}-0.099^{* * * *} \\
(-17.538)\end{array}$ & $\begin{array}{l}0.023^{* * * *} \\
(3.874)\end{array}$ & $\begin{array}{l}-0.030^{* * * *} \\
(-4.907)\end{array}$ & $\begin{array}{l}0.234^{* * *} \\
(42.686)\end{array}$ & 1.000 & & & \\
\hline Debt Coverage & $\begin{array}{l}0.034^{* * *} \\
(6.726)\end{array}$ & $\begin{array}{l}-0.321^{* * * *} \\
(-67.618)\end{array}$ & $\begin{array}{l}0.018^{* * *} \\
(3.607)\end{array}$ & $\begin{array}{l}0.015^{* * * *} \\
(3.045)\end{array}$ & $\begin{array}{l}-0.020^{* * * *} \\
(-3.943)\end{array}$ & $\begin{array}{l}0.134^{* * * *} \\
(26.669)\end{array}$ & $\begin{array}{l}0.110^{* * * *} \\
(21.862)\end{array}$ & $\begin{array}{l}0.304^{* * * *} \\
(63.538)\end{array}$ & $\begin{array}{l}0.225^{* * * *} \\
(44.156)\end{array}$ & $\begin{array}{l}0.096^{* * *} \\
(17.743)\end{array}$ & $\begin{array}{c}0.678^{* * * *} \\
(183.672)\end{array}$ & $\begin{array}{l}-0.020^{* * *} \\
(-3.605)\end{array}$ & 1.000 & & \\
\hline Altman Z-score & $\begin{array}{c}0.217^{* * * *} \\
(46.288)\end{array}$ & $\begin{array}{l}-0.440^{* * *} \\
(-102.177)\end{array}$ & $\begin{array}{l}-0.008^{*} \\
(-1.668)\end{array}$ & $\begin{array}{l}-0.239^{* * * *} \\
(-51.340)\end{array}$ & $\begin{array}{l}0.205^{* * * *} \\
(43.664)\end{array}$ & $\begin{array}{l}0.130^{* * * *} \\
(27.053)\end{array}$ & $\begin{array}{c}0.468^{* * * *} \\
(109.406)\end{array}$ & $\begin{array}{c}0.405^{* * *} \\
(92.169)\end{array}$ & $\begin{array}{l}0.404^{* * * *} \\
(87.854)\end{array}$ & $\begin{array}{l}0.023^{* * * *} \\
(4.405)\end{array}$ & $\begin{array}{c}0.506^{* * * *} \\
(122.243)\end{array}$ & $\begin{array}{l}0.348^{* * * * *} \\
(65.959)\end{array}$ & $\begin{array}{c}0.469^{* * * *} \\
(105.694)\end{array}$ & 1.000 & \\
\hline Tangibility & $\begin{array}{c}-0.433^{* * * *} \\
(-100.405)\end{array}$ & $\begin{array}{l}0.306^{* * * *} \\
(67.040)\end{array}$ & $\begin{array}{l}-0.035^{* * * *} \\
(-7.248)\end{array}$ & $\begin{array}{l}0.042^{* * * *} \\
(8.842)\end{array}$ & $\begin{array}{c}-0.670^{* * * *} \\
(-188.789)\end{array}$ & $\begin{array}{l}-0.106^{* * * *} \\
(-22.070)\end{array}$ & $\begin{array}{l}0.287^{* * *} \\
(61.775)\end{array}$ & $\begin{array}{l}-0.348^{* * * *} \\
(-77.219)\end{array}$ & $\begin{array}{l}0.144^{* * * * 4} \\
(28.850)\end{array}$ & $\begin{array}{l}0.065^{* * * *} \\
(12.580)\end{array}$ & $\begin{array}{l}-0.129^{* * *} \\
(-27.014)\end{array}$ & $\begin{array}{l}-0.240^{* * * *} \\
(-43.915)\end{array}$ & $\begin{array}{l}-0.138^{* * *} \\
(-27.665)\end{array}$ & $\begin{array}{l}-0.367^{* * * *} \\
(-82.159)\end{array}$ & 1.000 \\
\hline
\end{tabular}

${ }^{1}$ For definition of the variables see appendix I. All variables are measured in thousand of Euros, except ratios.

Significant at $1 \% ;{ }^{* *}$ Significant at $5 \% ;{ }^{*}$ Significant at $10 \%$. 


\section{APPENDIX V}

\section{Matrix of correlations - Portugal ${ }^{1}$}

\begin{tabular}{|c|c|c|c|c|c|c|c|c|c|c|c|c|c|c|c|}
\hline 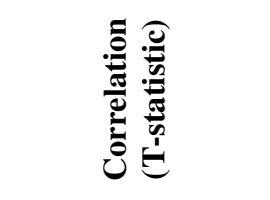 & 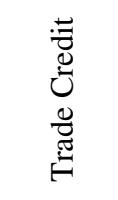 & 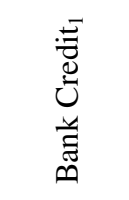 & 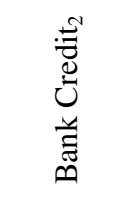 & $\stackrel{\tilde{N}}{i s}$ & 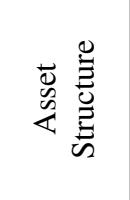 & $\mathbb{8}_{1}^{80}$ & 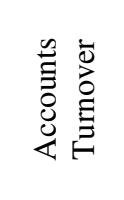 & 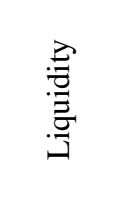 & 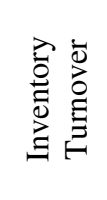 & 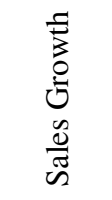 & 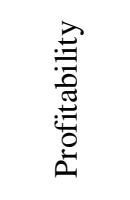 & $\begin{array}{l}\overrightarrow{0} \\
\overrightarrow{0} \\
\stackrel{\vec{U}}{\Xi}\end{array}$ & 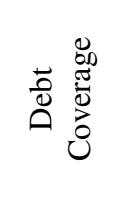 & 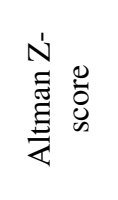 & 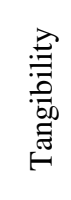 \\
\hline Trade Credit & 1.000 & & & & & & & & & & & & & & \\
\hline Bank Credit $_{1}$ & $\begin{array}{l}-0.350^{* * * *} \\
(-11.370)\end{array}$ & 1.000 & & & & & & & & & & & & & \\
\hline Bank Credit $_{2}$ & $\begin{array}{l}0.144^{* * * *} \\
(4.436)\end{array}$ & $\begin{array}{l}-0.494^{* * *} \\
(-17.304)\end{array}$ & 1.000 & & & & & & & & & & & & \\
\hline Size & $\begin{array}{l}0.319^{* * * *} \\
(10.246)\end{array}$ & $\begin{array}{l}-0.925^{* * *} \\
(-74.289)\end{array}$ & $\begin{array}{c}0.539^{* * * *} \\
(19.493)\end{array}$ & 1.000 & & & & & & & & & & & \\
\hline Asset Structure & $\begin{array}{l}0.436^{* * *} \\
(14.770)\end{array}$ & $\begin{array}{l}-0.777^{* * *} \\
(-37.602)\end{array}$ & $\begin{array}{l}0.448^{* * * *} \\
(15.250)\end{array}$ & $\begin{array}{c}0.765^{* * *} \\
(36.209)\end{array}$ & 1.000 & & & & & & & & & & \\
\hline Age & $\begin{array}{l}-0.285^{* * * *} \\
(-8.921)\end{array}$ & $\begin{array}{l}0.167^{* * *} \\
(5.098)\end{array}$ & $\begin{array}{l}0.183^{* * * *} \\
(5.589)\end{array}$ & $\begin{array}{c}0.036 \\
(1.0755)\end{array}$ & $\begin{array}{l}0.092^{* * *} \\
(2.786)\end{array}$ & 1.000 & & & & & & & & & \\
\hline Accounts Turnover & $\begin{array}{l}-0.354^{* * * *} \\
(-11.410)\end{array}$ & $\begin{array}{l}0.941^{* * * *} \\
(83.996)\end{array}$ & $\begin{array}{l}-0.482^{* * * *} \\
(-16.560)\end{array}$ & $\begin{array}{l}-0.903^{* * *} \\
(-63.447)\end{array}$ & $\begin{array}{l}-0.814^{* * * *} \\
(-42.280)\end{array}$ & $\begin{array}{l}0.102^{* * * *} \\
(3.068)\end{array}$ & 1.000 & & & & & & & & \\
\hline Liquidity & $\begin{array}{l}0.063^{*} \\
(1.908)\end{array}$ & $\begin{array}{c}-0.026 \\
(-0.801)\end{array}$ & $\begin{array}{l}-0.071^{* *} \\
(-2.148)\end{array}$ & $\begin{array}{c}0.008 \\
(0.253)\end{array}$ & $\begin{array}{c}0.002 \\
(0.075)\end{array}$ & $\begin{array}{c}-0.002 \\
(-0.063)\end{array}$ & $\begin{array}{c}-0.036 \\
(-1.095)\end{array}$ & 1.000 & & & & & & & \\
\hline Inventory Turnover & $\begin{array}{c}-0.055 \\
(-1.599)\end{array}$ & $\begin{array}{c}-0.009 \\
(-0.256)\end{array}$ & $\begin{array}{c}-0.046 \\
(-1.340)\end{array}$ & $\begin{array}{c}0.045 \\
(1.294)\end{array}$ & $\begin{array}{l}-0.132^{* * * *} \\
(-3.859)\end{array}$ & $\begin{array}{c}-0.020 \\
(-0.592)\end{array}$ & $\begin{array}{c}0.048 \\
(1.385)\end{array}$ & $\begin{array}{c}-0.035 \\
(-1.011)\end{array}$ & 1.000 & & & & & & \\
\hline Sales Growth & $\begin{array}{l}0.077^{*} \\
(1.940)\end{array}$ & $\begin{array}{c}-0.129^{* * * *} \\
(-3.272)\end{array}$ & $\begin{array}{l}0.083^{* * *} \\
(2.089)\end{array}$ & $\begin{array}{l}0.155^{* * * * *} \\
(3.959)\end{array}$ & $\begin{array}{l}0.137^{* * * *} \\
(3.492)\end{array}$ & $\begin{array}{c}-0.001 \\
(-0.024)\end{array}$ & $\begin{array}{l}-0.129^{* * * * *} \\
(-3.287)\end{array}$ & $\begin{array}{l}-0.004 \\
(-0.103)\end{array}$ & $\begin{array}{c}0.004 \\
(0.109)\end{array}$ & 1.000 & & & & & \\
\hline Profitability & $\begin{array}{l}0.338^{* * * *} \\
(10.944)\end{array}$ & $\begin{array}{c}-0.999^{* * *} \\
(-725.095)\end{array}$ & $\begin{array}{l}0.490^{* * * *} \\
(17.113)\end{array}$ & $\begin{array}{l}0.923^{* * * *} \\
(72.967)\end{array}$ & $\begin{array}{l}0.776^{* * * *} \\
(37.429)\end{array}$ & $\begin{array}{l}-0.164^{* * * *} \\
(-4.980)\end{array}$ & $\begin{array}{l}-0.941^{* * * *} \\
(-83.470)\end{array}$ & $\begin{array}{c}0.031 \\
(0.946)\end{array}$ & $\begin{array}{c}0.006 \\
(0.160)\end{array}$ & $\begin{array}{l}0.128^{* * * *} \\
(3.258)\end{array}$ & 1.000 & & & & \\
\hline Interest & $\begin{array}{l}0.152^{* * * *} \\
(4.580)\end{array}$ & $\begin{array}{l}-0.591^{* * *} \\
(-21.884)\end{array}$ & $\begin{array}{l}0.496^{* * * *} \\
(17.051)\end{array}$ & $\begin{array}{l}0.591^{* * *} \\
(21.907)\end{array}$ & $\begin{array}{c}0.469^{* * * *} \\
(15.845)\end{array}$ & $\begin{array}{c}0.040 \\
(1.180)\end{array}$ & $\begin{array}{l}-0.555^{* * *} \\
(-19.713)\end{array}$ & $\begin{array}{c}-0.043 \\
(-1.269)\end{array}$ & $\begin{array}{c}-0.008 \\
(-0.241)\end{array}$ & $\begin{array}{l}0.129^{* * * * * *} \\
(3.226)\end{array}$ & $\begin{array}{l}0.590^{* * * *} \\
(21.803)\end{array}$ & 1.000 & & & \\
\hline Debt Coverage & $\begin{array}{l}-0.084^{*} \\
(-1.742)\end{array}$ & $\begin{array}{l}0.258^{* * * *} \\
(5.528)\end{array}$ & $\begin{array}{l}-0.096^{* *} \\
(-2.001)\end{array}$ & $\begin{array}{l}-0.260^{* * * *} \\
(-5.588)\end{array}$ & $\begin{array}{l}-0.173^{* * * *} \\
(-3.645)\end{array}$ & $\begin{array}{c}0.047 \\
(0.972)\end{array}$ & $\begin{array}{l}0.250^{* * * *} \\
(5.314)\end{array}$ & $\begin{array}{l}0.117^{* * *} \\
(2.426)\end{array}$ & $\begin{array}{c}0.016 \\
(0.315)\end{array}$ & $\begin{array}{c}-0.042 \\
(-0.709)\end{array}$ & $\begin{array}{l}-0.255^{* * *} \\
(-5.471)\end{array}$ & $\begin{array}{l}-0.111^{* *} \\
(-2.313)\end{array}$ & 1.000 & & \\
\hline Altman Z-score & $\begin{array}{l}0.364^{* * * *} \\
(11.923)\end{array}$ & $\begin{array}{c}-0.998^{* * *} \\
(-518.427)\end{array}$ & $\begin{array}{l}0.489^{* * * *} \\
(17.064)\end{array}$ & $\begin{array}{c}0.922^{* * * *} \\
(72.783)\end{array}$ & $\begin{array}{c}0.780^{* * * *} \\
(37.985)\end{array}$ & $\begin{array}{l}-0.174^{* * * *} \\
(-5.302)\end{array}$ & $\begin{array}{l}-0.938^{* * *} \\
(-81,419)\end{array}$ & $\begin{array}{c}0.038 \\
(1.140)\end{array}$ & $\begin{array}{c}-0.045 \\
(-1.313)\end{array}$ & $\begin{array}{l}0.132^{* * * *} \\
(3.354)\end{array}$ & $\begin{array}{c}0.999^{* * * *} \\
(567.416)\end{array}$ & $\begin{array}{l}0.593^{* * * *} \\
(21.971)\end{array}$ & $\begin{array}{c}-0.253^{* * * *} \\
(5.426)\end{array}$ & 1.000 & \\
\hline Tangibility & $\begin{array}{l}-0.202^{* * * *} \\
(-6.266)\end{array}$ & $\begin{array}{c}0.134^{* * * *} \\
(4.097)\end{array}$ & $\begin{array}{c}-0.213^{* * * *} \\
(-6.604)\end{array}$ & $\begin{array}{c}-0.191^{* * * *} \\
(-5.908)\end{array}$ & $\begin{array}{l}-0.834^{* * *} \\
(-45.936)\end{array}$ & $\begin{array}{l}-0.351^{* * * *} \\
(-11.224)\end{array}$ & $\begin{array}{l}0.403^{\text {**** }} \\
(13.207)\end{array}$ & $\begin{array}{c}-0.023 \\
(-0.688)\end{array}$ & $\begin{array}{l}0.115^{* * * *} \\
(3.343)\end{array}$ & $\begin{array}{l}-0.040 \\
(-1.007)\end{array}$ & $\begin{array}{c}-0.033 \\
(-1.013)\end{array}$ & $\begin{array}{c}-0.047 \\
(-1.399)\end{array}$ & $\begin{array}{l}-0.012 \\
(-0.249)\end{array}$ & $\begin{array}{c}-0.155^{\text {**** }} \\
(-4.771)\end{array}$ & 1.000 \\
\hline
\end{tabular}

${ }^{1}$ For definition of the variables see appendix I. All variables are measured in thousand of Euros, except ratios.

Significant at $1 \% ;{ }^{* *}$ Significant at $5 \% ;{ }^{*}$ Significant at $10 \%$. 


\section{REFERENCES}

ANAND, B. N. and GALETOVIC, A. (2006): "Relationships, competition and the structure of investment banking markets", The Journal of Industrial Economics, 54 (2): 151-199.

ARELLANO, M. (2003): "Panel data Econometric”, Oxford University Press.

ARELlANO, M. and BOND, S. (1991): "Some tests of specification for panel data: Monte Carlo. Evidence and an application to employment equations", Review of Economic Studies, 58:277197.

BECK, T.; DEMIRGÜÇ-KUNT, A. and MAKSIMOVIC, V. (2003) "Financial and Legal Institutions and Firm Size", Working Paper, World Bank.

BERGER, A. N. and FRAME, S. (2006): "Small Business Credit Scoring and Credit Availability", Journal of Small Business Management, 45 (1): 5-22.

BERGER, A. N.; GOLDBERG, L.G. and WHITE, L. J. (2001): "The Effects of Dynamic Changes in Bank Competition on the Supply of Small Business Credit", European Finance Review 5: 115-139.

BERGER, A. N.; KLAPPER L. F. and UDELL G. F. (2001): "The ability of banks to lend to informationally opaque small businesses", Journal of Banking \& Finance, 25: 2127-2167.

BERGER, A. N.; MILlER, N. H.; PETERSEN, M. A.; RAJAN, R. G. and STEIN, J. C. (2005): "Does function follow organizational form? Evidence from the lending practices of large and small banks", The Journal of Finance Economics, 76: 237-269.

BERGER, A. N.; ROSEN R. J. and UDELL G. F. (2007): "Does market size structure affect competition? The case of small business lending", Journal of Banking \& Finance, 31: 11-33.

BERGER, A. N. and UDELL, G. F. (1995): "Relationship lending and lines of credit in small firm finance", Journal of Business, 68 (3): 351-381.

BERGER, A. N. and UDELL, G. F. (2002): “ Small Business Credit Availability and Relationship Lending: The Importance of Bank Organisational Structure", The Economics Journal, 112: $32-53$.

BERGER, A. N. and UDELL, G. F. (1998): "The economics of small business finance: The roles of private equity and debt markets in the financial growth cycle", Journal of Banking \& Finance, 22 (8): 613-673.

BERLIN, M. (2003): “Trade Credit: Why do Production Firms Act as Financial Intermediaries?", Business Review, Federal Reserve Bank of Philadelphia, Q3: 21-28.

BERNANKE, B. S. and BLINDER, A. (1988): "Credit, Money and Aggregate Demand", American Economic Review, 78 (2): 435-439.

BIAIS, B. and GOLLIER, C. (1997): “Trade Credit and Credit Rationing”, The Review of Financial Studies, 10 (4): 903-937.

BIAIS. B.; HILLION, P. and MALÉCOT, J. F. (1995): "La Structure Financière des Entreprises: Une Investigation Empirique sur Données Française", Economie et prevision, 120: 15-28.

BLASIO, G. (2005): "Does Trade Credit Substitute Bank Credit? Evidence from Firm-level Data", Economic Notes by Banca Monte dei Paschi di Siene SpA, 34 (1): 85-112. 
BOND, P. (2005): "Bank and Nonbank Financial Intermediation”, Journal of Finance, 59 (6): 24892529.

BONFIM, D.; DAI, Q. and FRANCO, F. (2008): "The number of bank relationships and the cost of borrowing. An empirical study" paper presented at European Financial Management Association, 25 - 28, June, Greece.

BOOT, A. W. A. and THAKOR, A. V. (2000): "Can Relationship Banking Survive Competition?", The Journal of Finance, 55 (2): 679-713.

BREIG, (1994): "Bank Lending and Corporate Financing in Major Industrial Countries: Are France and Germany Really Similar?, Working Paper, Albert Ludwing Universitat, Breisgau.

BRENNAN, M. J., MAKSIMOVIC, V. and ZECHNER, J. (1988): "Vendor Financing”, Journal of Finance, 43 (5): 1127-1141.

BRICK, I. E. and FUNG, W. K. H. (1984): "Taxes and the Theory of Trade Debt", Journal of Finance, 39 (4): 1169-1176.

BURKART, M. and ELLINGSEN, T. (2004): "In-Kind Finance: A Theory of Trade Credit", The American Economic Review, 94 (3): 569-590.

BURKART, M.; GIANNETTI, M. and ELlingSEN, T. (2004): "What You Sell is What You Lend? Explaining Trade Credit Contracts", CEPR Working Paper N. ${ }^{\circ} 4823$ (http://ssrn.com/abstract=702928).

CAMERON, R. (1967):"Banking in the early stages of industrialization", New York, Oxford University Press.

CANOVAS, G. H. and SOLANO, M. P. (2006): "Banking Relationships: Effects on Debt Terms for Small Spanish Firms", Journal of Small Business Management, 44 (3): 315-333.

COOK, L. D. (1997): “Trade Credit and Bank Finance: Financing Small Firms in Russia”, Journal of Business Venturing, 14: 493-518.

DEGRYSE, H. and ONGENA, S. (2007): "Competition and regulation in the banking sector: A review of empirical evidence on the sources of bank rents", in Thakor, A. and Boot, Handbook of Financial Intermediation and Banking (Elsevier) forthcoming.

DEMIRGÜÇ-KUNT, A. and MAKSIMOVIC, V. (2001): "Firms as Financial Intermediaries: Evidence from Trade Credit Data", World Bank Policy Research Working Paper $n^{\circ} 2696$ (http://ssr.com/abstract=632764)

DETRAGIACHE, E.; GARELLA, P. and GUISO, L. (2000): "Multiple versus Single Banking Relationships: Theory and Evidence”, The Journal of Finance, 55 (3): 1133-1161.

DIAMOND, D. (1984) "Financial Intermediation and Delegated Monitoring", Review of Economic Studies, 51: 393-414.

DIAMOND, D. (1991) "Monitoring and Reputation: The Choice between Bank Loans and Directly Placed Debt”, Journal of Political Economy, 99: 689-721.

EMERY, G. (1987): “An Optimal Financial Response to Variable Demand”, Journal of Financial and Quantitative Analysis, 22 (2): 209-225.

FERRIS, J. S. (1981): “A Transactions Theory of Trade Credit Use”, Quarterly Journal of Economics, 94 (2): 243-270. 
FISHMAN, R. and LOVE, I. (2003) “Trade Credit, Financial Intermediary Development and Industry Growth", Journal of Finance, 58 (1):353-374.

FRANK, M. and MAKSIMOVIC, V. (2005): "Trade Credit, Collateral, and Adverse Selection”, Working Paper, University of Maryland (http://ssrn.com/abstract=87868).

FREIXAS, X. (1993): “Short-Term Credit versus Accounts Receivable Financing”, Universitat Pompeu Fabra Economics, Working Paper, 27: 1993.

GIANNETTI, M. (2003): "Do Better Institutions Mitigate Agency Problems? Evidence from Corporate Finance Choices" Journal of Financial and Quantitative Analysis, 38 (1): 185-212.

GRAIG, S. G. and HARDEE, P. (2007): "The impact of bank consolidation on small business credit availability”, Journal of Banking \& Finance, 31: 1237-1263.

GUEDES, J.C. and MATEUS, C. (2008): Trade Credit Linkages along a supply chain: Evidence for the Italian Textile sector", paper presented at $5^{\text {th }}$ Portuguese Finance Network (PFN), 10-12 July, Coimbra.

HAUSMAN, J. (1978): “Specification Tests in Econometrics”, Econometrica 46: 1251-1272.

IAPMEI - Instituto de Apoio às Pequenas e Médias Empresas e ao Investimento (2007): “PME em números", http://www.iapmei.pt.

JAIN, N. (2001) "Monitoring Costs and Trade Credit", Quarterly Review of Economics and Finance, 41 (1): 89-110.

KARCESKI, J.; ONGENA, S. and SMITH, D. C. (2005): “The Impact of Bank Consolidation on Commercial Borrower Welfare", The Journal of Finance, 60 (4): 2043-2082.

LEE, Y. W. and STOWE, J. D. (1993): "Product Risk, Asymmetric Information and Trade Credit", Journal of Financial and Quantitative Analysis, 28 (2): 285-300.

LELAND, H. and PYLE, D. (1977): "Informational Asymmetries, Financial Structure, and Financial Intermediation”, Journal of Finance, 32: 371-387.

LEHMANN, E. and NEWBERGER, D. (2001): "Do lending Relationships Matter? Evidence from Bank Survey Data in Germany", Journal of Economic Behavior and Organization, 45:339359.

LONG, M. S.; MALITZ, I. B. and RAVID, S. A. (1993): “Trade Credit, Quality Guarantees and Product Marketability”, Financial Management, 22 (4): 117-127.

MATEUT, S. and MIZEN, P. (2002): "Trade Credit and Bank Lending: An investigation into the determinants of UK Manufacturing Firms", Access to trade credit, Working Paper.

MELTZER, A.H. (1960) "Mercantile Credit, Monetary Policy, and Size of Firms", Review of Economics and Statistics, 42 (4): 429-443.

MYERS, S. (1977): "Determinants of Corporate Borrowing”, Journal of Financial Economics, 5 (2):147-175.

MYERS, S. and MAJLUF, N. S. (1984): "Corporate financing and investment decisions when firms have information that investors do not have", Journal of Financial Economics, 13: 187-221.

MYERS, S. and RAJAN R. G. (1998): “The Paradox of liquidity”, Quarterly Journal of Economics, 113 (3): 733-771. 
NADIRI, M. I. (1969): "The Determinants of Trade Credit in the U.S. Total Manufacturing Sector", Econometrica, 37 (3): 408-423.

NEVES, J. C. (2006): “Análise Financeira”, Texto Editores, $17^{\text {a }}$ Edição.

NG, C.K.; SMITH, J.K. and SMITH, R.L. (1999) "Evidence on Determinants of Credit Terms Used in Interfirm Trade”, Journal of Finance, 54 (3): 1109-1129.

NILSEN, J. H. (2002) "Trade Credit and Bank Lending Channel”, Journal of Money, Credit and Banking, 34 (1): 226-253

PETERSEN, M. A. and RAJAN, R. G. (1994): “The Benefits of Lending Relationships: Evidence from Small Business Data", The Journal of Finance, 49 (1): 3-37.

PETERSEN, M. and RAJAN, R. (1995) "The Effect of Credit Market Competition on Lending Relationships", Quarterly Journal of Economics, 110 (2):407-443.

PETERSEN, M. A. and RAJAN, R. G. (1997): "Trade Credit: Theories and Evidence", The Review of Financial Studies, 10 (3): 661-691.

RAJAN, R. (1992): "Insiders and Outsiders: The Choice Between Informed and Arm's -Length Debt", Journal of Finance, 47 (4):1367-1400.

RAMEY, V. (1992) “The Source of Fluctuations in Money: Evidence from Trade Credit”, Journal of Monetary Economics, 30:171-193.

SCHWARTZ, R.A. (1974) “An Economic Model of Trade Credit”, Journal of Financial Quantitative Analysis, 9: 643-657.

SCHWARTZ, R. A. and WHITCOMB, D. (1978): "Implicity Transfers in the Extension of Trade Credit", in Kenneth E. Boulding and Thomas F. Wilson, eds. The channels of redistribution through the financial system. New York, Praeger: 191-208.

SCHWARTZ, R. A. and WHITCOMB, D. (1979) "The Trade Credit Decision” In James L. Bicksler, ed. Handbook of Financial Economics, Amsterdam: North-Holland: 257-2773.

SHARPE, S. (1990): “Asymmetric Information, Bank Lending and Implicit Contracts: A stylized Model of Customer Relationships”, Journal of Finance, 45 (4): 1069-1087.

SMITH, J. K. (1987): Trade Credit and Informational Asymmetry”, Journal of Finance, 42, (4): 863869.

STIGLITZ, J. and WEISS, A. (1981): "Credit Rationing in Markets with Imperfect Information", American Economic Review, 71: 393-410.

VON THADDEN, 1994: “The Commitment of Finance, Duplicated Monitoring and the Investment Horizon", Working Paper.

WILNER, B. S. (2000): “The Exploitation of Relationships in Financial Distress: The Case of Trade Credit”, The Journal of Finance, 55 (1): 153-178. 


\section{Curriculum vitae}

Agosto, 2008

INFORMAÇÃO PESSOAL

$\begin{array}{ll}\text { Nome } & \text { Teixeira, Andreia Manuela Martins } \\ \text { Morada } & \begin{array}{l}\text { Monte - Refontoura } \\ \text { 4610-696 Felgueiras }\end{array} \\ & 962323920 \\ \text { Telemóvel } & \text { teixeira.adr@gmail.com } \\ \text { Correio electrónico } & \text { Portuguesa } \\ \text { Nacionalidade } & 29-06-1984 \\ \text { Data de nascimento } & \text { Solteira } \\ \text { Estado civil } & \end{array}$

\section{FORMAÇÃO ACADÉMICA E PROFISSIONAL}

- Frequência no "Mestrado em Economia Financeira" na Universidade da Beira Interior, desde Setembro de 2007:

i) $1 .^{\circ}$ Semestre: parte lectiva;

ii) 2. ${ }^{\circ}$ Semestre: realização da dissertação de mestrado intitulada: "Does trade credit facilitate access to bank finance? An empirical evidence from Portuguese and Spanish small medium size enterprises".

- Licenciatura de Economia pela Universidade da Beira Interior, com média de 13 valores (Setembro/2002 a Junho/2006).

- Frequência do $1^{\circ}$ semestre do $4^{\circ}$ ano da Licenciatura em Economia, na Universidad de Valladolid, España, ao abrigo do programa Erasmus, (Outubro de 2005 até Fevereiro de 2006).

- Frequência e aprovação de curso de Inglês, em Harrow House International College, Londres, Inglaterra, desde 16 Agosto de 2005 até 31 de Agosto de 2005.

- Curso Livre de Inglês, com duração de 45 horas, na Universidade da Beira Interior, desde Março de 2005 até Junho de 2005.

\section{ACTIVIDADE PROFISSIONAL}

- Gestora comercial na Caixa Geral de Depósitos, desde 4 de Junho de 2007;

- Formação bancária, por técnicos da Caixa Geral de Depósitos, desde 4 de Junho de 2007 até 19 de Junho de 2007.

CONFERÊNCIAS

Paper "Does trade credit facilitate access to bank finance? An empirical evidence from Portuguese and Spanish small medium size enterprises"aceite na "31st Institute for Small Business \& Entrepreneurship Conference", Belsfat - N. Irlanda, 5-7 Novembro 2008.

\section{APTIDÕES E COMPETÊNCIAS SOCIAIS}

- Responsável pedagógica do Núcleo de Economia, da Universidade da Beira Interior no biénio 2002/2003 e 2003/2004.

- Delegada de turma em vários anos lectivos.

- Realização do conservatório de música.

\section{APTIDÕES E COMPETÊNCIAS DE ORGANIZAÇÃO}

- Organização de três semanas de Economia, na Universidade da Beira Interior, em 2002/2003 e 2003/2004

- Organização do CNEEG (Congresso Nacional de Economia e Gestão) em 2004/2005. 